\title{
20. YÜZYILDA MOBÍLYA TASARIMI AKIMLARINA GENEL BİR BAKIŞ
} AN OVERVIEW OF FURNITURE DESIGN STYLES IN THE 20TH CENTURY

\author{
Süphan Kaan ÇIFTCí ${ }^{1}$ - Deniz DEMIRARSLAN ${ }^{2}$
}

\section{$\ddot{O} \mathbf{z}$}

20. Yüzyıl dünyada her alanda gelişim ve değişimin olduğu bir çağdır. Sanayileşme ve teknolojinin gelişmesi ile yeni malzemeler ve yeni üretim teknikleri ortaya çıkmıştır. Tasarımcılar gelişen teknolojiyle birlikte eskimiş ve sıradanlaşmış durumda olan akımları terk etmişlerdir. Mimari tasarım, mobilya tasarımı ve sanat alanlarında birçok yeni akım ortaya çıkmıştır. Bu dönemde mimari üsluplarla birlikte gelişen mobilya tasarım üslupları İkinci Dünya Savaşı Öncesi ve İkinci Dünya Savaşı Sonrası dönemler olmak üzere iki ana başlık altında incelenmektedir. Çalışmanın amacı, yeterli Türkçe yazılı kaynak bulunmayan 20. yüzyıl mobilya akımları hakkında bilgiler sunmak ve 20.yüzyılın tasarım akımlarını özetleyerek araştırmacılara bir başvuru kaynağı oluşturmaktır. Çalışma derleme makale niteliğinde, nitel araştırma yöntemlerinden biri olan gözlem metodu alt başlığında literatür taraması yöntemi kullanılarak yapılmıştır. Çalışmanın sonucunda 20. yüzyıl mobilya tasarımı akımlarının tablo halinde önemli özelliklerine değinilmiş ve karşılaştırılmalar yapılmıştır.

Anahtar Kelimeler: Modernizm, Postmodernizm, Minimalizm, Bauhaus, Art Deco.

\begin{abstract}
The 20th century is an age of development and change in every area of the world. New materials and new manufacturing methods have emerged with the advancement of industrialization and technology. Designers discarded old and ordinary styles with the advancement of technology. Many new trends have emerged in the fields of architectural design, furniture design and art. Furniture design styles developed with architectural styles in this period are examined under two main headings as the periods before and after the Second World War. The purpose of the study is to provide information on furniture movements of the 20th century, for which there are not enough Turkish written sources, and to create a reference source for researchers by summarizing the design trends of the 20th century. The study was conducted as a review article using the literature review approach under the subtitle of the observation method, which is one of the qualitative research methods. As a result of the study, important features of the 20th century furniture design trends are mentioned and compared in the form of a table.
\end{abstract}

Keywords: Modernism, Postmodernism, Minimalism, Bauhaus, Art Deco.

\footnotetext{
${ }^{1}$ İç mimar, Kocaeli Üniversitesi, Sosyal Bilimler Enstitüsü, İç Mimarlık Ana Sanat Dalı suphanciftci@gmail.com, Orcid: 0000-0001-5875-142X

2 Doç. Dr., Kocaeli Üniversitesi, İç Mimarlık Bölümü, demirarslandeniz@ gmail.com, Orcid: 0000-0002-78175893
} 


\section{Giriş}

İki büyük Dünya Savaşının yaşandığı dönem, ekonomik buhranlar, siyasi ve politik birçok gelişimin yaşandığı 20.yüzyıl, insanlık adına birçok alanda değişimin de olduğu bir dönemdir. Say eserinde (2003, s.62) 20. yüzyıl boyunca ekonomik, sosyal ve politik ilişkilerde kaydedilen gelişmelerle Orta Çağ sonlarından itibaren olgunlaşmaya başlamış olan modern örgütlenme biçimlerinin bu dönemde değişmeye başladığını ifade etmektedir. Küreselleşme ve tüketim kültürünün ortaya çıkması ve yaygınlaşması, yeni malzemelerin kullanımı ve üretim teknolojilerinin gelişmesi endüstri ve tasarımı ilgilendiren tüm alanlarda da 20. Yüzyılın diğer dönemlerden farklı bir hale gelmesini sağlamıştır.

Sanayileşme ve teknolojik gelişmeler her alanda yer bulmuş ve insanların hayatlarını kolaylaştırmayı hedeflemiştir. Kentleşmenin artması ile birlikte gereksinimleri karşılamak için mobilya endüstrisi I. Dünya Savaşından önce gelişmeye ve değişmeye başlamıştır. Antik dönemlerden itibaren sürekli toplum ve kültürlere göre gelişim gösteren mobilya 20. Yüzyılın başında teknoloji, anlayış ve kullanım açısından değişmeye başlamıştır. 20. yüzyıl ile birlikte endüstri toplumu oluşmuş, el işçiliği eski değerini kaybetmiştir. Ancak yine de el işçiliğine önem veren kesimler varlığını sürdürmüştür.

20. yüzyılın ilk on beş yılında yenilikçi mobilyaların en önemli özellikleri süsten uzak, sade geometrik biçimlerde olmalarıydı. Genelde düz çizgiler, dik açılar kullanılmaktaydı. Ancak gerekli alanlarda işlevsel olarak eğimli mobilyalar da tasarlanıyordu. Mimarlık ve mobilya tasarımının yakın ilişki içinde olduğu bu dönemde birçok mimar "Gesamkuntswerk" yani "Bütüncül Tasarım" anlayışı ile aynı zamanda mobilya tasarımları da yapmışlardır. Bu nedenle 20.yüzyılda bazı mobilya tasarımı akımları ile mimarlık akımlarının örtüştüğü ve birbirlerini etkiledikleri görülmektedir (Tablo- 1).

Tablo-1: 20.Yüzyılda Mobilya Tasarım Akımları ve Mimari Akımlar

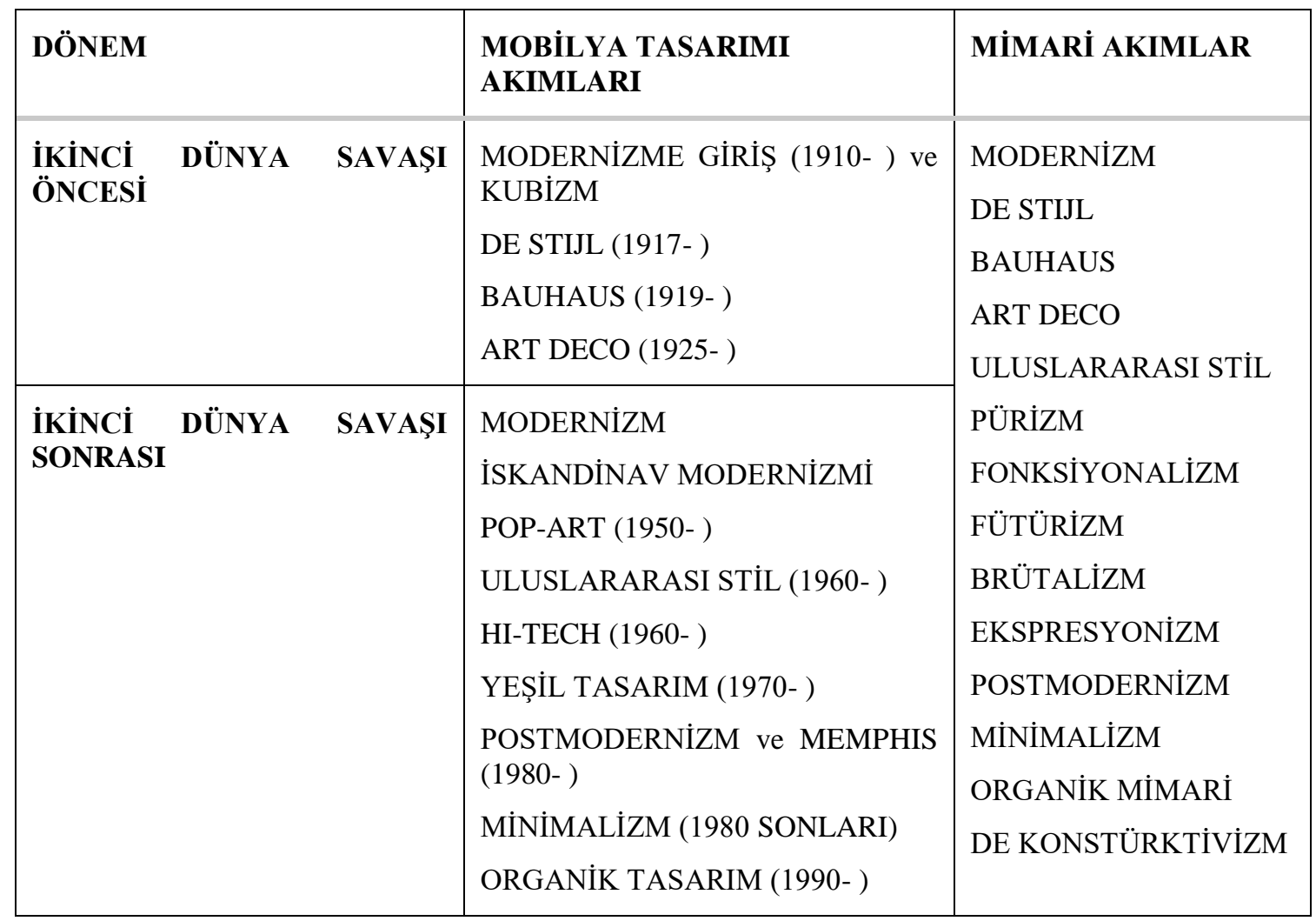


20. yüzyıl mobilya endüstrisi İkinci Dünya Savaşı öncesi ve İkinci Dünya Savaşı sonrası olmak üzere iki ayrı dönemde incelenir. Savaş öncesi dönemde Modernizme giriş yapılmış, De Stijl, Bauhaus ve Art Deco akımı ortaya çıkmıştır. Savaş sonrası dönemde endüstri tasarımı önem kazanmış ve diğer disiplinlerden ayrı bir uzmanlık alanı olarak kabul edilmeye başlanmıştır. İkinci Dünya Savaşı sonrası dönemde Modernizme geçiş yapılmıştır. Amerika savaşa katılmasına karşın ülkesinde ve askeri alanlarda çok büyük kayıplar vermemesinden dolayı savaş sonrasında hızlıca toparlanmış ve çeşitli sentetik malzemeler, yeni metal alaşımlarla birlikte endüstri alanına yeni imkânlar sağlamıştır (Massey, 1996, s.163).

20.yüzyıl iç mimarlık ve mimarlık disiplinlerine ortak sayılabilecek birçok akımı ortaya çıkarmıştır. Modernizm, Bauhaus, De Stijl, Fütürizm, Neo-Plastisizm, Fonksiyonalizm, Pürizm, Brütalizm, Ekspresyonizm, Postmodernizm, Minimalizm, De Konstrüktivizm gibi akımları hayatımıza kazandırmıştır. Bunun yanı sıra Modernizm, Pop-Art, Uluslararası Stil, Hi-tech, Yeşil Tasarım, Postmodernizm, Minimalizm, Organik Tasarım gibi akımlar 20.yüzyılın başlıca mobilya akımları olmuşlardır (Tablo- 1).

Çalışma kapsamında 20. Yüzyılda mobilya tasarımında kullanılan başlıca üsluplar nitel araştırma yöntemlerinden biri olan gözlem metodu altında literatür tarama yöntemi ile incelenmiştir. 20. Yüzyılda mobilya tasarımını etkileyen çok fazla sayıda üslup bulunmaktadır ve yazılı kaynaklara göre bu üslupların sınıflandırılması farklılıklar göstermektedir. $\mathrm{Bu}$ çalışmada ise üsluplar yaygın bir şekilde, kaynaklardaki sınıflandırmalar esas alınarak belirlenmiş ve makale kapsamında alt başlıklar altında incelenmiştir.

\section{20. Yüzyıl Mobilya Akımları}

Yukarıda da belirtildiği üzere, 20.yüzyıl mobilya akımları, "'̇kinci Dünya Savaşı Öncesi" ve "İkinci Dünya Savaşı Sonrası" dönem olarak iki ayrı ana başlık altında incelenmektedir (Boyla, 2012, s.103; Massey, 1996, s.145).

\section{1. İkinci Dünya Savaşı Öncesi Mobilya Tasarımı}

İkinci Dünya Savaşı öncesi dönemde görülen mobilya tasarımı akımları Modernizme Giriș ve Kübizm, De Stijl, Bauhaus ve Art Deco'dur. Her ne kadar Art Nouveau üslup ve Art \& Crafts hareketi 20. Yüzyılın ilk yıllarında da etkilerini sürdürmüş olmakla birlikte bu çalışma kapsamında sadece tamamı 20. Yüzyılın içinde görülen üsluplara yer verilmiştir.

\subsubsection{Modernizme Giriş}

Modernist hareket ilk olarak 19.yüzyılın ortalarında görülmüştür. Sadelik ve işlevselliğe verilen önem artmış, halka yönelik tasarımlar gündeme gelmiştir. 1860'lı yıllarda, stil, işçilik ve halkın zevkinden rahatsız olan bir grup bulunmaktaydı. Bunların arasında İngiliz reformcu, şair ve tasarımcı olan William Morris, 1861 yılında iç dekoratörler ve imalatçılar ile bir firma kurdu. Morris, Philip Webb, Madox Brown ve Edward Burne-Jones, takı, duvar kâğıdı, tekstil, mobilya ve kitap üretmiştir (Url-1). Bu sanatçılar endüstriye karşı olarak geleneksel el sanatlarını tekrar canlandırmayı hedeflemişlerdir. İngiltere'de başlayıp daha sonra bütün Avrupa ve Kuzey Amerika'ya yayılan bu hareket "El Sanatları Akımı", (Arts and Crafts Movement) adı ile anılmaktadır. 19.yüzyılın ortalarında başlayan bu hareket Birinci Dünya Savaşı'ndan sonraki yıllara değin etkili olmuştur. Mobilyalarında çoğunlukla masif ahşap (özellikle meşe) kullanılmış, ağaçların damarlarını belirginleştirecek mat cilalar tercih edilmiştir. Birçok örnekte Japon tasarımının etkileri görülmüştür. Mobilyalar sade, düz yüzeyli tablalar ile oluşturulurdu. Uygun olan alanlara (dolapların yan yüzeyleri, koltuk kenarları vb.) kafesler ya da düz dikdörtgen biçimli parmaklıklar yerleştirilirdi. Az sayıda 
oyma, kakma ya da marküteri yöntemleri kullanılarak yapılan küçük desenler yüzeyleri süsleyebiliyordu. Gotik süsleme öğeleri de çok kullanılırken, Türk halı ve çinilerini hatırlatan doku ve desenlere de rastlanılırdı. Bu hareket her ülkede kendine özgü gelişimler göstermiştir. Art Nouveau ve Art Deco akımları, bu akımdan doğmuştur. 20.yüzyılın ilk yarısında ortaya çıkan ilk endüstriyel tasarımcılar da yine bu hareketten gelmektedir (Boyla, 2012, s.94). Bu tasarımcılar arasında yer alan Peter Behrens, Dünya tarihinde kurumsal kimlikle özdeşleşmiş ilk endüstriyel tasarımcı olarak bilinir.

Art Nouveau, Fransizcada 'yeni sanat' anlamına gelen, sanat ve tasarım alanlarında kıvrımlı çizgilerin, yoğun bitki ve zarif biçimde hayvan motiflerinin ve kadın figürlerinin kullanıldığı bir akımdır. 19. Yüzyılın sonları ile 20. Yüzyılın başlarında altın çağını yaşamıştır (Özakın, 2018, s. 242). Art Nouveau, tüm tarihi göndermeleri reddetmiş, insanı ve insan yaşantısını merkezine almış, bolca tasarlanmış görsel bir dil geliştirmek amacıyla kullanmıştır (Ambrose ve Harris, 2010, s.33). Art Nouveau üslubu tüm tarihi göndermeleri reddetmesiyle modernizme 1şık tutmuştur.

Art Nouveau mobilyaları bulundukları mekân ile bütünleşmek amacıyla tasarlanmaktaydi. Mobilya yüzeylerinde yer alan dekoratif unsurlar yer, duvar ve tavanda tekrarlanırdı. Perde, halı ve döşemelik kumaşlar da bu uyumu devam ettirmek üzere dokunurdu. Diğer yandan bu mobilyalar içinde bulundukları mekanları bölümlere ayırmak amacı ile de kullanılırdı. Birçok mobilya farklı fonksiyonları yerine getirmek üzere karmaşık bir yapıda tasarlanırdı. Bu akımda işlevsellik ve mekân bütünlügü en az sanatsal ifade kadar önemliydi (Boyla, 2012, s.95-96). Hector Guimar, Eugene Gaillard, Emile Gallé, Louis Majorelle, Victor Horta, Henry van de Velde, Antoni Gaudi, Charles Rennie Mackintosh, Art Nouveau akımının önemli temsilcileri arasında yer almaktadır. Mackintosh'un Helensburgh'ta bulunan Hill House için 1904 yılında tasarladığ 1 sandalye önemli bir örnek teşkil etmektedir. Art Nouveau başta mimarlık olmak üzere, mücevher ve takı tasarımı, cam sanatı, seramik ve afiş tasarımlarında kendisini göstermiştir.

20. yüzyılın başında Adolf Loos'un "Süs suçtur" manifestosu sadeliğe verilen önemi anlatmaktadır. Esasen bir mimar olan Loos, dönemin Gesamtkuntswerk -Bütüncül Tasarım anlayışı gereği tasarımın her alanında eserlerini ortaya koymaktaydı (Şekil-1). Bu anlayışa göre bir mimar sadece binaları tasarlamakla kalmıyor içindeki mobilyaları ve diğer nesneleri de tasarlayabiliyordu. Le Corbusier ise yaşamı kolaylaştıran diğer gereçler gibi evin de ekonomik ve teknik olanaklar ölçüsünde modern insanın ihtiyaçlarını karşılayan bir gereç olduğunu savunmuştur (Boyla, 2012, s.102) (Şekil-1). Bu dönem, Joseph Gocar başta olmak üzere Kübist tasarımcıların yapmış olduğu süsten arınmış mobilya tasarımları ile Modernizmin doğuşuna öncülük eden bir aşama olarak kabul edilmektedir (Şekil- 2). Esasen Kübik mobilya Kübik mimariden etkilenmiştir. Günümüzde Prag Kübizm Müzesi'nde özgün Kübik mobilya örneklerini görmek mümkündür (Şekil-2).

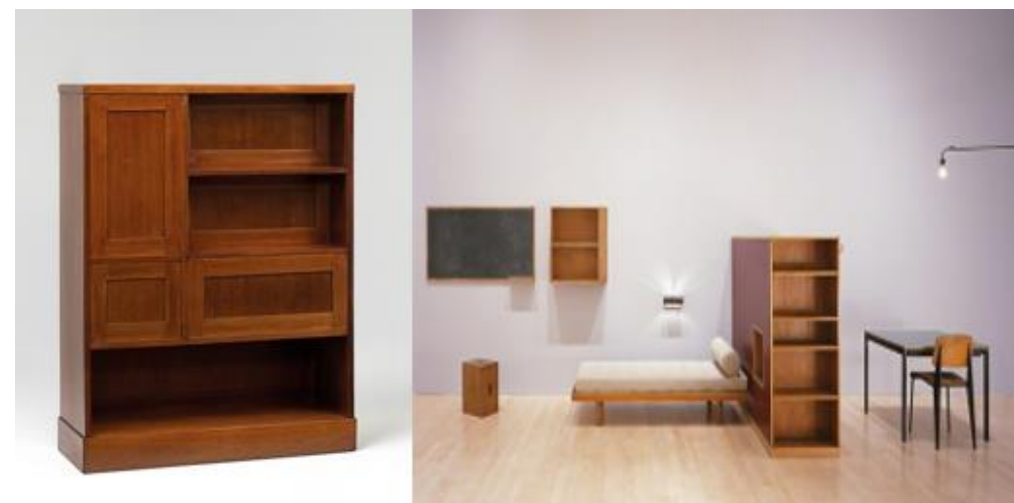

Şekil 1. Adolf Loos Tasarımı Kitaplık, 1903 Viyana (URL-2) ve Le Corbusier ve Charlotte Perriand Tasarımı Bir Odada Mobilyalar (URL-3). 


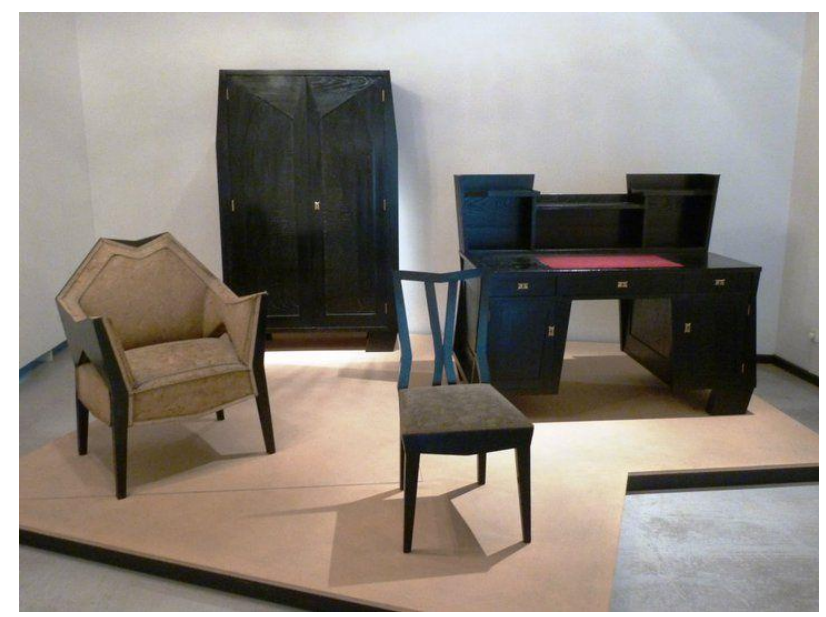

Şekil 2. Çek Asıllı Tasarımcı Joseph Gocar'in Kübik Mobilya Tasarımları, Kübizm Müzesi Prag (URL-4).

\subsubsection{De Stijl}

1917 y1lında Hollanda'nın Rotterdam şehrinde “'De Stijl” isimli derginin yayınlanması bir grup aydın ve sanatçının ortak bir paydada ve yeni bir dünyada buluşmasına olanak sağlamıştır. Bu sanatçılar teknolojinin insanların yararına eşit bir dünya kurmak adına kullanılmasını istiyorlardı. Bu doğrultuda De Stijl 1917 yılından 1928 yılına kadar örgütlü bir akım olarak karşımıza çıkmaktadır. En ünlü sanatçıları arasında Mondrian, Theo Van Doesburg ve Gerrit Rietveld yer almaktadır. De Stijl, geleneksel olarak kullanılan simetri yerine asimetriyi ve dik açılı geometrik cisimleri kullanmıştır. Amaç tüm insanlar için ortak bir dil oluşturmaktı. Bu sebeple sadece temel geometrik biçimleri ve ana renkleri kullanmışlardır (Boyla, 2012, s.102). Tasarımlarda kırmızı, sarı ve mavi ana renklere siyah ve beyaz eşlik etmiştir.

De Stijl akımının en önemli mobilya ürünü sayılan mimar Rietvelt'in tasarımı Red and Blue İskemlesi, estetik ve işlevsellik açısından bir plastik eserin tüm elemanlarını varlığında simgelemektedir (Ateş, 2014, s.23) (Şekil- 3). Birçok ahşap parçadan oluşan iskemlede yukarıda da belirtildiği gibi sarı, kırmızı ve mavi ana renkler kullanılmıştır. Mobilyanın tasarımında Mondrian resminin sembolikleştiği bir üçüncü boyut görülmektedir (Sofuoğlu, Ertaş, vd, 2019, s.6751-6760). Eriç, ve diğerlerinin (1986) çalışmalarında belirtildiği üzere; bu akımın özelliği, makine ile üretim için en uygun biçim ve şekillerin geliştirilmesi, el işçiliği ve süslemenin en aza indirilmesidir (akt. Ateş, 2014, s.24). Yalınlık, sanatsal sezgi, ana renkler, evrensellik, teknik, pratiklik ve estetik uyumun iç içe olması De Stijl mobilyanın öne çıkan özellikleridir. Tasarımlarda düz çizgilerle birlikte, dikdörtgen, yuvarlak, kare gibi basit geometrik formlar kullanılmıştır. Forma eşlik eden ana ve nötr renkler de soyut kurgunun ifadesidir. Yine Rietveld'in tasarlamış olduğu Zigzag İskemle ise detay özellikleri açısından teknoloji sınırlarını zorlarken, ergonomi konusunu arka planda bırakmıştır. Rietveld'in 1934 yılında tasarladığ 1 dört adet ahşap plakadan oluşan bu iskemle aynı zamanda minimalist bir tasarım olarak da kabul edilmektedir (Mori, Obuchi vd, 2016, s.257) (Şekil-4). Oturma ergonomisi ve konforun göz ardı edildiği düşünülen bu iskemlenin günümüzde seri üretilerek satışa sunulan ve iç mekânlarda tercih edilen bir tasarım olması ilgi çekicidir. 

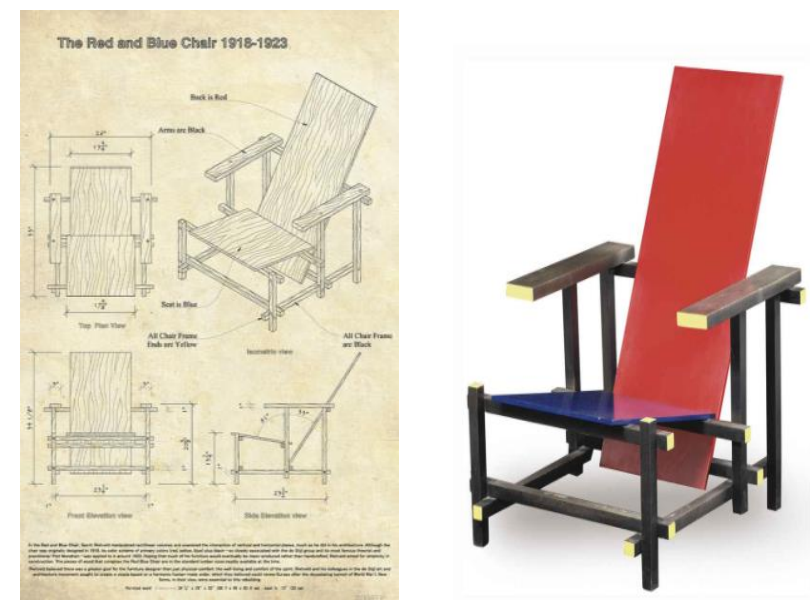

Şekil 3. Red and Blue İskemlesi Teknik Çizim ve Prototipi, Gerrit Rietveld (URL-5).

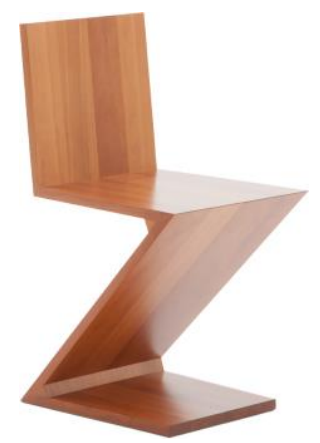

Şekil 4. Zigzag İskemle (1934), (Mori, Obuchi vd, 2016:257).

\subsubsection{Bauhaus}

1919 yılında Walter Gropius tarafından Weimar şehrinde kurulan Bauhaus Okulu'nda yaratıcı gücü destekleyen ve deneysel bir tasarım laboratuvarı niteliğindeki eğitim kapsamında mimarlığın temel sanat olarak kabul edildiği diğer sanat dallarının mimarlığa hizmet ettiği fikri benimsenmiştir. Böylelikle endüstriyel tasarım, iç mekân ve mimarlığın bir bütün olarak ele alınması, bunların endüstri ile iş birliğinin sağlanması amaçlanmıştır. Mimarlık, resim ve heykel sanat dalı altında marangoz ve metal işçiliği, dokumacılık atölyelerinde mobilya çalışmaları yapılan okulda Bauhaus anlayışının temelini sanatsal ve uygulamalı eğitim oluşturmaktaydı. Tasarımda nesnel yaklaşım kabul edilmekteydi (Bulat, Bulat vd., 2014, s.105-120). Böylelikle okulun eğitim sistemi kapsamında temel zanaat bilgisi, tasarım ilkeleri ve uygulama esasları bir araya getirilmişti.

Kurulduğu yıllarda Bauhaus Okulunun ilk amacı temel bir mimarlık, zanaat ve güzel sanatlar akademisi oluşturmaktı. Ancak savaştan sonra Gropius'a göre yeni bir mimari döneme başlamanın zamanı gelmişti. İşlevin ön planda yer aldığı, kalıcı ve ucuz ürünlerin üretileceği yeni bir dönem başlamalıydı (Şekercioğlu, 2017, s.44). Bauhaus bildirisine göre tüm sanatların birleştiği en yüksek nokta mimarlıktı ve mimari eser olan binalar yeni üslubun önemli temsilcileriydi.

1925 yılında okul, Dessau'daki yeni yerleşkesine geçmiş ve endüstri kurumlarıyla daha fazla ilişkiler kurmaya özen göstermiştir. Bu dönemlerde öğretim görevi üstlenen bazı eski öğrencilerle birlikte dışarıdan eğitim kadrolarına katılan genç mimar ve tasarımcılar, mobilya alanında yenilikçi denemelere başlamışlardır (Boyla, 2012, s.103). Şahinkaya'nın eserinde (2009, s.36) belirttiği üzere, Bauhaus mobilyayı incelemeden önce Bauhaus'un öncüsü olan Deutscher Werkbund'un mobilya tasarımına yaklaşımından bahsetmek gerekir. Deutscher Werkbund'un sloganı "iyi form” olmuştur. "İyi form” teknolojik bir rasyonalizmi 
ve işlevselciliğin doğurduğu bir kalite anlayışını ifade etmektedir. Süsten arınmış bir bütünlük içerisinde çevresiyle ve kendisiyle uyum sağlayan objeler üreten Werkbund, süsün her türlüsüne Art Nouveau ve Arts and Crafts akımlarının aksine, aşırı ve lüks olarak bakmıştır.

Werkbund etkisiyle Bauhaus mobilya tasarımı "yeni yaşam" isteğiyle üretilen modern mimarlığın iç mekanlarında yer almıștır. Marcel Breuer, Mies van der Rohe başta olmak üzere Erich Dieckmann, Peter Keller, Alma Buscher gibi isimler bu alanda kendilerini göstermişlerdir (Şekil-5). Endüstriyel malzeme kullanımı, hafiflik, hijyen, biçimde yalınlık, konstrüktif yapı, strüktürün açıkça görülmesi, detaylarda basitlik, ana renklerin kullanımı, rengin işlevi ve strüktürü tanımlaması gibi özellikler bütüncül tasarım anlayışı gösteren Bauhaus mobilyanın başlica özellikleri olup, metal, cam ve deri en fazla kullanılan malzemeler olmuştur. Bauhaus'un bireyciliği ve özgürlüğü öne çıkaran, bununla birlikte disiplinler arası çalışmayı her zaman destekleyen yapısı mobilya tasarımının ana temasını oluşturmuştur. Birinci Dünya Savaşı öncesi dönemde ahşap, mobilyada kullanılan temel malzeme iken, Bauhaus ile birlikte metal malzemenin mobilya tasarımında yaygin olarak kullanımı söz konusudur. Metal malzeme üretimde masif ahşaba göre ucuz olması, mukavemeti, seri üretime uygunluğu, ambalajlama kolaylığ mobilyada ahşabın yerine geçmiştir (Droste, 2002, s.82). Mobilyadaki tüm gelişmeler mobilya tasarımında üretime yönelik standartlaşma ve rasyonalizasyon konusunu gündeme getirmiştir. Bunun yanı sıra montaj kolaylığı, yeni teknoloji kullanarak daha yüksek kalite gibi ilkeler günümüze kadar gelen mobilya endüstrinin temelini oluşturmaya başlamıştır.

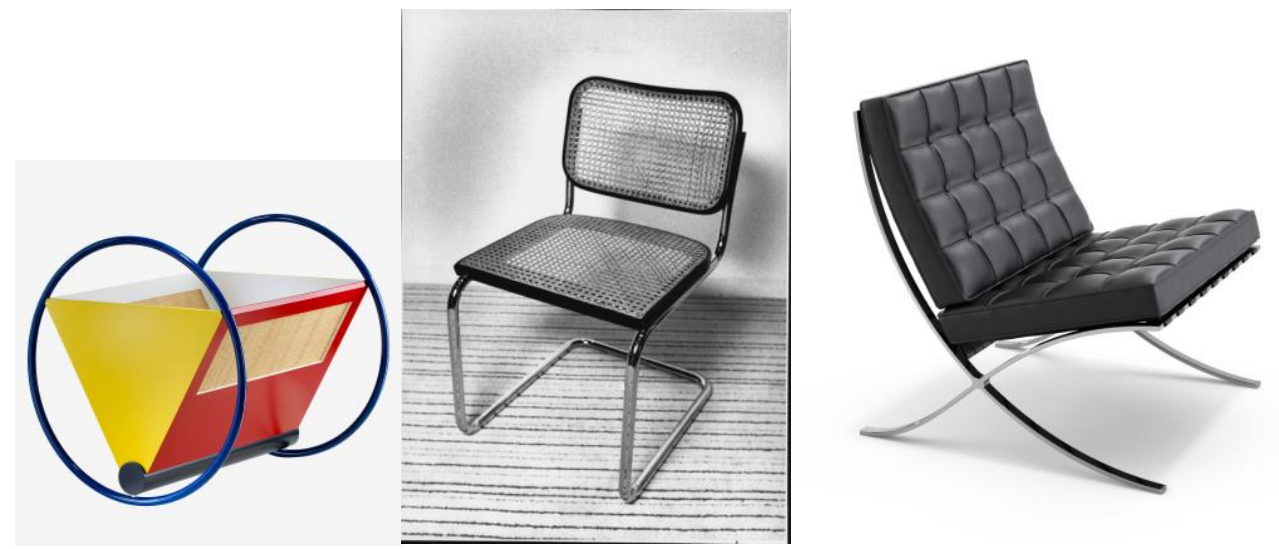

Şekil 5. Kandinsky Resminden İlham Alan Beşik, Peter, Keller, 1923(URL-6); Cesca İskemle, Marcel Brauer (URL-7); Barcelona İskemlesi Ludwig Mies Van Der Rohe, 1929 (URL-8).

\subsubsection{Art Deco}

Kökeni Paris olan ve buradan Avrupa'ya yayılan Art Deco akımı, Art Nouveau akımından hemen sonra gelmiştir. Geometrik desenlere sahip olan bu üslupta Art Nouveau'da da olduğu gibi gotik süslemelerden yararlanılmıştır. 1930'lu yıllardan sonra süslemenin yerini işlevselliğin alması ile akım son bulmuştur. Ancak 1967 yılında Bonnie ve Clyde filminin gösterime girmesiyle Art Deco akımı yeniden revaçta olmuştur. Tasarım, sanat ve kültürde Pop-Art akımın devam ettiği bu dönemde Art Deco ile birlikte Art Nouveau çizgileri de yeniden gündeme gelmiştir (Massey, 1996, s.175). Savaş sonrası Modernizm akımı ile beraber Fütürizm, Kübizm, Pürizm, Fovizm gibi sanat akımlarının etkisinde kalmıştır. Bu akımla üretilen mobilyalarda sedef, abanoz, fildişi, gümüş, altın, leopar ve kaplan postlarıyla parlak renklere sahip ipek kumaşlar en çok kullanılan malzemelerdir. İşlevsellik yerine lüks ve pahalı tasarımlar yapılmış ve Hollywood filmleri bu mobilyaların insanlar tarafindan beğeni kazanması için bir aracı olmuştur (Ateş, 2014, s.26; Massey, 1996, s.114). Özetle, Art Deco geçmiş sanat akımlarından izler taşımasına rağmen, stilin ana özelliği geleceğe de 
yönelmiş olmasıdır. Kendinden önceki üsluplara göre kavramsal açıdan zayıf olarak nitelendirilmesine rağmen yaygın hale gelmesinde filmler önemli bir rol oynamıştır.

Art Deco tasarımcıları, eski saray mobilyacılarının kullanmakta olduğu geleneksel tekniklerle üretim yapıyorlardı. Henüz yonga levhalar imal edilmezken çok özenli işçilikler yapılıyordu. Mobilyalarda çeşitli katmanlar ile oluşturdukları yaklaşık olarak $3 \mathrm{~cm}$ kalınlığında kaplamalı levhalar kullanılıyordu. Yüzeylerinde marküteri tekniği ile yapılan süslemeler yer almaktaydı. Mobilyada kullanılan ağaçlara büyük önem veriliyor; köklerden, budaklı dallardan ve gövdelerin belirgin bir şekilde desenler gösteren kesitleri ile elde edilen kaplamalar tercih ediliyordu. Özellikle 1930'lu yıllardan önce maun, abanoz, Afrika zeytini, gül ağacı gibi ağaçlardan üretilmiş mobilyalar mekanları süslemekteydi (Boyla, 2012, s.108). Léon Jallot, Jacques-Emile Ruhlmann, Eileen Gray, Andre Leleu dönemin önemli mobilya tasarımcıları arasında yer almaktadır. Bu dönemde taşıtlardan mimariye dek her yerde kullanılan ve hızın simgesi olan Streamline çizgisi mobilyada da açıkça görülmektedir (Şekil$6)$.

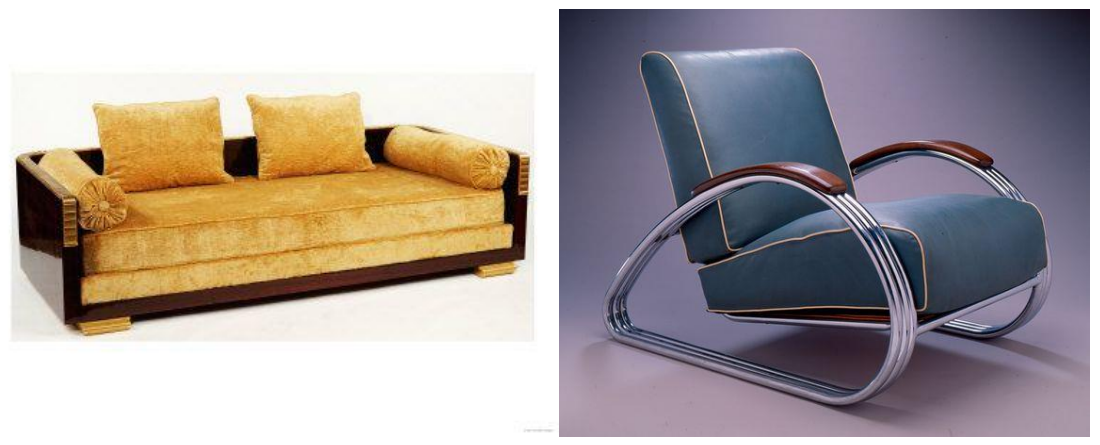

Şekil 6. Day Bed, Jacques-Emile Ruhlmann, 1920 (URL-9), Streamline Bir Koltuk (URL-10).

\section{2. İkinci Dünya Savaşı Sonrası Mobilya Tasarımı}

Dünya genelinde büyük bir yıkım ve yeni bir yapılanma getiren İkinci Dünya Savaş1 yeni bir üretim tarzı ortaya koymuştur. Daha çok maliyet hesabına yönelen, daha kaliteli ve daha hızlı bir endüstriyel üretim şekli gündeme gelmiştir. Mobilyalarda sentetik yapıştırıcılar, polyester, akrilik, polietilen reçine gibi yeni malzemeler geliştirilmiştir. Modernizm, İskandinav Modernizmi, Pop Art, Uluslararası Stil, Hi-Tech, Yeşil Tasarım, Postmodernizm, Minimalizm ve Organik Tasarım mobilya tasarımı alanında yaygın olarak bu dönemde görülen önemli tasarım akımları olarak karşımıza çıkmaktadır.

\subsubsection{Modernizm}

Savaşın sona ermesine yakın bir zamanda Batı Avrupa'da De Stijl Grubu Modernist düşünceleri yaygınlaştırarak tasarımda uygulamaya koymaya çalışırken, 1917 yılında komünist bir devrimi gerçekleştirmiş olan Rusya'da da Konstrüktivizm ve Süprematizm yepyeni bir toplum düzeni kurmanın heyecanı ile ortaya çıkmıştır (Julier,1993, s.131). Bu düzen içinde her türlü üretim makinelerinin kullanıldığ tasarımı söz konusuydu. Tasarım sokaktaki sıradan kişilerin günlük gereksinimlerini karşılamak için yapılmalıydı. Doğaya üstünlük kazanmış olan insanın yarattığı dünyada rüyaların yerini gerçekler, fantezilerin yerini bilimsel olarak kanıtlanmış bulgular almalıydı. Karmaşıklık önlenmeli; kolay algılanabilir, saydam çevreler yaratılmalıydı. Bu amaçla metal ve deri malzemenin ağırlıklı olarak kullanıldığı tasarımlar düz çizgi, daire, kare, prizma ve silindir gibi doğada bulunmayan basit geometrik biçim ve kitlelerle meydana getirilmeliydi. $\mathrm{O}$ dönemde temel renkler olarak kabul edilen kırmızı, sarı, mavi yanında siyah, beyaz ve gri kullanılmalıydı (Boyla, 2012, s.102). Böylelikle akımın ana ilkeleri olan sadelik, işlevsellik ve 
ekonomiklik özellikleri yerine getirilirken bir yandan da yapılan tasarımların yaygın bir şekilde kabul görmesiyle akım evrensellik kazanmıştır.

Boyla eserinde (2012, s.104) Modernist mobilya anlayışını şu sözlerle açıklamaktadır; "Estetik düzen bütünün parçaları arasındaki orantılar, doku, biçim, renk ve parlaklık gibi konulardaki zıtllklar ve yapım sırasında gösterilen özenle meydana getirilirdi. İnsan bedenine uyum ve kullanım rahatlı̆̆ göz ard edilmiyordu, ancak bu nitelikler hedefledikleri ekonomik çerçeve elverdiğince gerçekleştirilebiliyordu".

20. yüzyılın en önemli tasarım akımı olmasına rağmen bütüncül tasarım anlayışının egemen olduğu Modernizm hareketinin temeli 19. Yüzyılın ortalarında atılmaya başlamıştır. Özünde daha işlevsel ve sade olana yönelme fikri yer almaktaydı ve modernleşme sürecinin gelişmesinde, biçimlenmesinde kültürel, toplumsal ve politik alanlarda yaşanan büyük kargaşaların etkisi olmuştur (Şekercioğlu, 2017, s. 47). Isamu Noguchi, Marcel Breuer, Eileen Gray, Jos De Mey, Mies Van Der Rohe, Le Corbusier önemli mobilya tasarımları ile döneme imzalarını atmışlardır ( Şekil- 7).

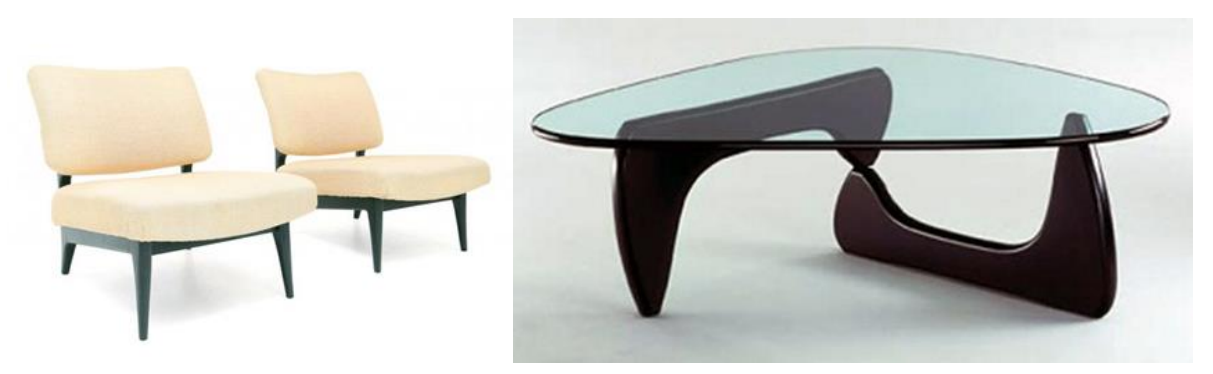

Şekil 7. Easy Chair, Jos De Mey, 1950 (URL-11); Noguchi Table, 1947, Isamu Noguchi (URL-12).

\subsection{2. İskandinav Modernizmi}

İskandinav Modernizmi ya da diğer adıyla İskandinav Tasarımı, 20. yüzyılın başlarında ortaya çıkan ve daha sonra 1950'lerde Norveç, İsveç, Finlandiya, Danimarka ve İzlanda'dan oluşan beş İskandinav ülkesinde gelişen basitlik, minimalizm ve işlevsellik ile karakterize edilen bir tasarım hareketidir. 1914 y1lında Danimarka'da Danish Selskabet for Dekorativ Kunst Firması tarafından çıkarılan bir dergi bu tarzın doğmasına öncülük etmiştir. 1930'lardan itibaren Alvar Aalto, Arne Jacobsen, Borge Mogensen, Hans J. Wegner, Verner Panton gibi tasarımcılar İskandinav tasarımının altın çağının oluşmasına yardımcı olmuştur. Gereksiz hiçbir ayrıntıya yer verilmeyen bu üslupta doğal ve yapay ahşap malzeme temel gereçtir. Özellikle kontrplak kullanımının en güzel örnekleri görülebilmektedir. Bu tarzın öne çıkan özelliklerinden biri de düzenli ve derli toplu bir görünümün hâkim olmasıdır. $\mathrm{Bu}$ nedenle mobilyaların işlevsel olması, strüktürünün algılanabilir olması ön planda tutulmuştur (Fiell, 2003, s.8) (Şekil-8). Modernizmde metal ve cam malzeme ağırlıklı olarak kullanılırken, İskandinav Modernizminde doğal ahşap ve kompozit ahşap malzeme teknolojisinin en nadide örnekleri ortaya konmuştur. 


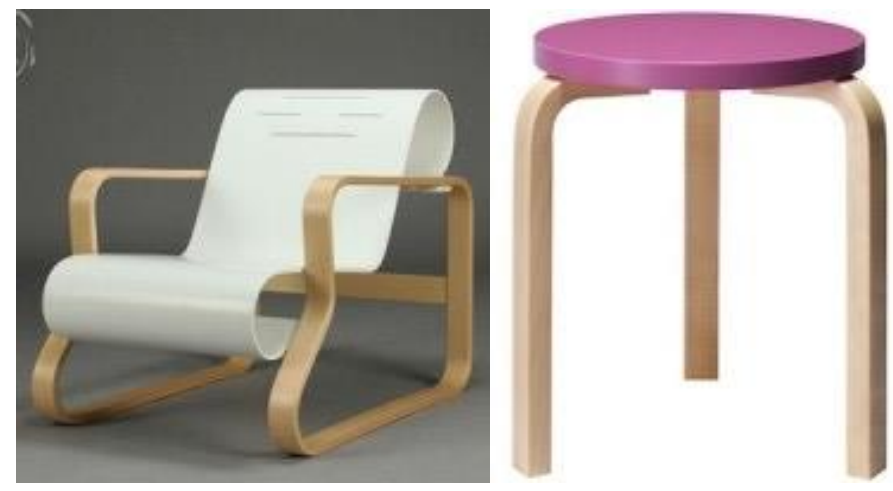

Şekil 8. Alvar Aalto Tasarımı Koltuk ve Tabure (URL-13).

\subsubsection{Pop-Art}

Pop-art İkinci Dünya Savaşı'ndan sonra Amerika'da gelişmiş bir akımdır. Andy Warhol başta olmak üzere sanatçılar eserlerinde günlük hayatta kullanılan sıradan objeleri, yayın organlarındaki tekrarlanan olayları ve halkın ilgilendiği kişileri konu almışlardır. Sanatçılar illüstrasyonla sınırlı kalmamış, sinema da dahil tüm sanat alanlarında eserler ortaya koymuşlardır. $\mathrm{Bu}$ akımın mobilya tasarımına yansıması kısa bir sürede gerçekleşmiştir. Pop tasarımda plastik malzemeler başlıca kullanılan malzemeler olmuştur. 60'lı yıllarda eğlenceli, bol renkli, oyuncak benzeri, dönemin popüler konularını hatırlatan eşyalar ve mobilyalar görülmektedir. İngiltere'de sanatçı Allen Jones'in plastik malzeme ile yapılmış çıplak kadın figürlerinden masa, iskemle ve askılık, Paolo Lomazzi'nin Marliyn Monroe'nun eşi beyzbol oyuncusu olan Joe di Maggio'ya gönderme ile yapılmış Joe isimli beyzbol eldiveni şeklindeki koltuk bu akıma örnek olarak gösterilebilir (Şekil-9). Pop-Art'1 Richard Hamilton "halkın zevkine uygun, kısa süreli, harcanabilir, ucuz, endüstri ürünü, genç, esprili, cinsel çekiciliği olan, göz alıcı ve kârlı iş", olarak tanımlıyordu (Boyla, 2012, s.124). Akımın en önemli tasarımcılarından olan George Nelson, sürekli olarak teknoloji ve fikirler keşfetmiş, bu fikirleri de tasarımlarıyla buluşturmuştur. Herkes tarafından bilinen, yaygın anlamlarına gelen "popüler" kelimesinin kısaltması olan "Pop" 1960'lı yıllarda Amerikalı eleştirmenler tarafindan kullanılmasıyla bir sanat akımının ismi olmuştur (Ateş, 2014, s.27). John Makepeace, Fred Baier, Alan Paters akımın diğer önemli tasarımcıları arasında yer alır.
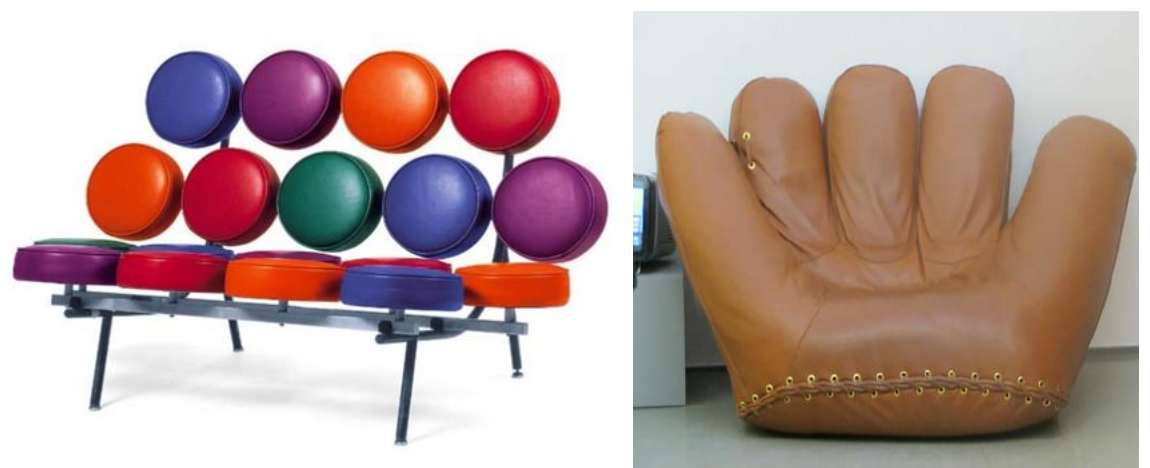

Şekil 9. Marshmallow Sofa, George Nelson, 1956 (URL-14); Paolo Lomazzi Joe Chair, 1970 (URL-15).

\subsubsection{Uluslararası Stil}

Uluslararası Stil temelini 1930'ların modern hareketinden alan basitlik, faydacılık ve sadeliği savunan bir akımdır. Bazı tasarım tarihçileri 30'lu yıllardaki tasarımları öncü Modernizm olarak tanımlamaktadırlar. Bu stilde tarihselcilik ve süslemeler yerini tamamen işlevselliğe bırakmıştır (Julier, 1993, s.105; Gössel, 1990, s.234). 1940 ve 50'li yıllarda fiberglas, pleksiglas, kauçuk sünger gibi yapay malzemeler tasarımcılar için büyük bir 
özgünlük yaratmıştır. 1960'larda kullanılmaya başlanan sentetik malzemelerin çeşitliliğinin artmasıyla mobilya tasarımında biçim çeşitliliği de artmıştır. Yeni malzemeler ve teknolojinin etkisiyle mobilya tasarımında sınırsız renk çeşitliliği kullanılmıştır (Khan, 1998, s.65). Mobilyalar artık endüstri ürünü olarak düşünülüp üretilmekteydi. 1960'ların başlarında Modernist çizgiyi devam ettiren tasarımcılar malzemenin en az düzeyde kullanıldığı bir sadelik, çok hareket bulunmayan akıcı hatlar, detay yetkinliğiyle beraber çok irdelenmiş biçim kaygısına sahiptiler. İnsanların rahatlığı düşünülerek tasarımlar yapılırken değerli malzemeler de kullanılmaktaydı. Bu zengin tarzda mobilyalar seçici bir zevki yansıtmaktaydı. Tüketimin artmasına bağlı olarak ofis, konaklama mekanları, lokantalar, kafeteryalar, ulaşım terminallerinin sayıları tüm dünyada artmaktaydı. Dünyanın genelinde kullanılan bu mekanlarda en uygun mobilyalar endüstri ürünü, sade, akılcı, rahat ve kişiliği çok fazla belirgin olmayan minimal ve modern tarzda mobilyalar olarak karşımıza çıkmaktadır (Boyla, 2012, s.123). Arne Jacobsen, Warren Platner, Charles Eames ve Ray Eames bu üslubun tasarımcıları arasında yer alır (Şekil-10).
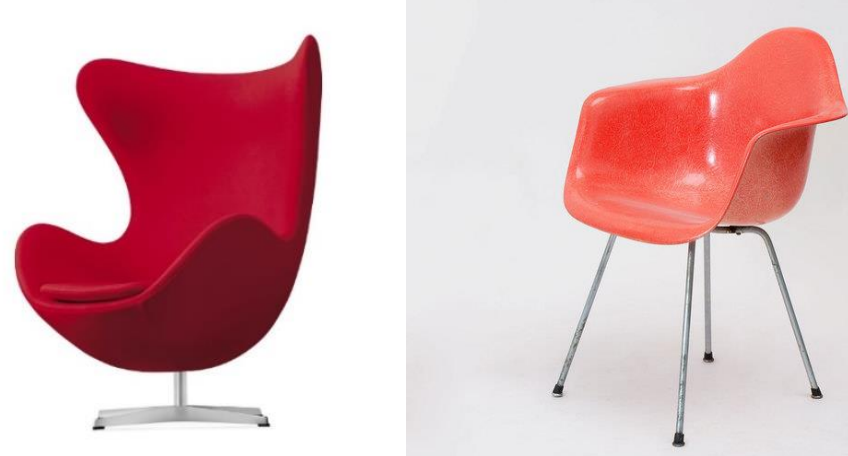

Şekil 10. Egg Chair, Arne Jacobsen, 1958; DAX Shell Armchair (URLl-16), Charles \&Ray Eames, 1953 (URL-17).

\subsubsection{Hi-Tech}

İngilizce yüksek teknoloji kelimelerinin kısaltılması ile oluşan bu terim endüstri ürünü metal, cam, plastik gibi işlenmiş olan malzemelerle yaratılan mobilya ve mekânlar için kullanılmaktaydı. Akım büyük kentlerde kullanılmayan endüstri yapılarında yaratılan loft tarzı mekanlarda oluşmuştu (Boyla, 2012, s.131). 20. yüzyılın ikinci yarısından günümüze kadarki süreç içerisinde loft konut anlayışı; kullanıcı ihtiyaçları, istek ve gereksinimleri doğrultusunda, değiştirilebilir, kişiselleştirmeye uygun, duvarlarla sınırlandırılmayan, genellikle endüstriyel, özgün ev vizyonu sunan, dönüşüm öncesi genellikle üretim yapıları olmaları ve endüstriyel işlevlere yönelik tasarlanmaları dolayısıyla serbest plan, bir tür iç, esnek ve tek mekân organizasyonuna sahip konut türü olarak tanımlanmaktadır (Işıkkaya, 2015, s.209). 1950'li ve 60'lı yıllarda ucuza kiralanan bu geniş mekânlar sanatçılar için atölye olarak hizmet veriyordu. İnşaat artığı demir, hurda saç ve borulardan oluşturulan strüktürlerle bu mekânlarda masalar ve tezgahlar, duvarlarda raflar ve yüksek tavanlı mekânlarda yatak odası, büro olarak asma katlar yaratıyorlardı. Bu mekânlar dünyanın geneline yayılmaya başlamıştı. 1970'li yıllarda ekonomik sebeplerle ortaya çıkmış ve atık endüstri malzemelerle oluşan bu tasarımlar, öncü mimarların ütopik tarzda arayışlarından ve piyasada bulunan oyuncak gibi ve renkli mobilyalardan usanmış bazı tasarımcıların esin kaynağı olmuştur. Bauhaus'a göndermeler içeren, minimalist tasarım ile yakından ilişkili olan ve gerçekçi çözümlemelerle yeni bir akımın oluşmasına sebep olunmuştur (Boyla, 2012, s.131). Basit geometrik formlu ve genelde tek rengin hâkim olduğu, metal malzemenin ağırlıklı olarak kullanıldığı mobilyalar modüler olarak da tasarlanmıştır. Rodney Kinsman, Michael Hopkins ve Richard Rogers bu akımın öncüleri olmuşlardır (Kron ve Slesin, 1984) (Şekil-11). Günümüzde ise Hi-Tech mobilya ve iç mekân akıllı teknoloji ile birleştirilerek fütüristtik bir 
yaklaşımla ele alınmaktadır (Şekil-11). Akıllı ev teknolojileri kapsamında uzaktan kontrol sistemleriyle teknolojik ev gereçlerinin mobilya ile entegrasyonu söz konusu olduğu gibi mobilyanın da yüksek teknolojik ilavelerle geliştirilmesi mümkün olmuştur. Örneğin dijital mobil cihazlara şarj imkanı sunan kanepeler, sensörlü dolap içi aydınlatması olan mobilyalar ya da dijital yatak, dijital giyinme odaları gibi örnekler mevcuttur (Demirarslan ve Demirarslan, 2020, s.571). Ayrıca 3D Yazıcı sistemlerinin kullanımıyla mobilyanın çok daha basit bir şekilde üretimi mümkün hale gelmiştir. Yapay zekâ teknolojisinin mobilyaya uyarlanması ile akıllı mobilya sistemlerinin 21. Yüzyılda yaygın bir şekilde kullanılacağı öngörülmektedir.

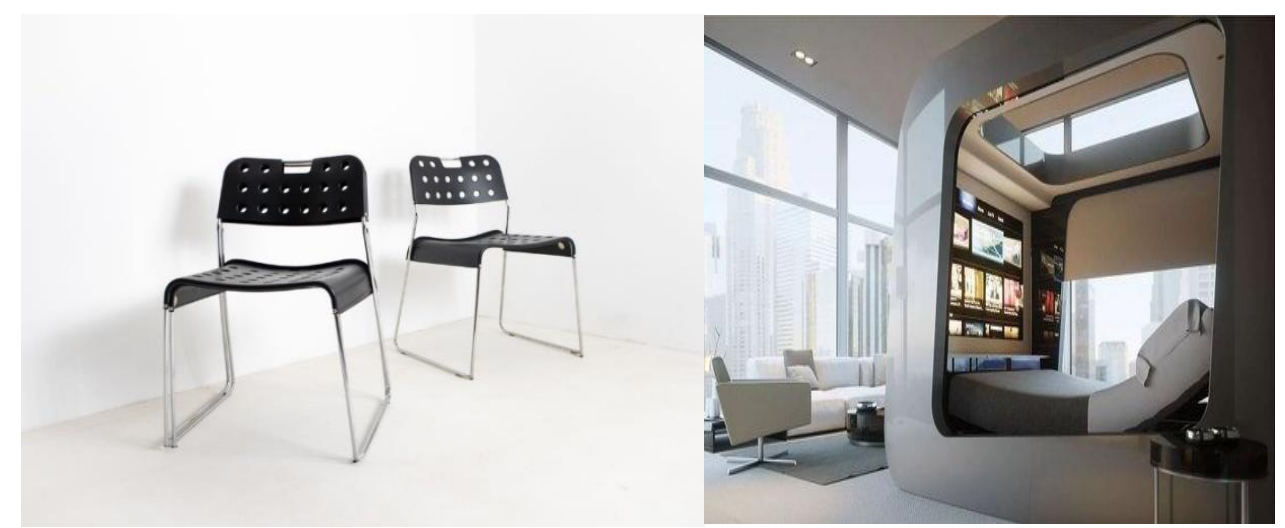

Şekil 11. Omkstak Chair, Rodney Kinsman, 1972 (URL-18); ve Günümüzde Hi-Tech Mobilyada Akıllı Teknoloji Kullanımı (URL-19).

\subsubsection{Yeșil Tasarım}

Yeşil Tasarım 1980'li yılların sonlarına doğru isimlendirilmiş bir tasarım anlayışı olup, bu alandaki çalışmalar 1950'li yıllara dayanmaktadır. Buckminister Fuller, Richard Neutra gibi tasarımcılar çevre dostu bir yaklaşımla tasarımlarını ele alırken, 60'lı yılların sonunda Victor Papanek "ihtiyaç için tasarım” kapsamında çevreci bir yaklaşımla mobilyalar tasarlamıştır (Julier, 1993, s.95). 1971 yılında yaşanan petrol krizi nedeniyle dünyadaki doğal kaynakların daha ekonomik kullanılması gündeme gelmiş; her alanda olduğu gibi mobilya tasarımı alanında da çevreci yaklaşımlar önemle dikkate alınmaya başlamıştır. Dönüşüm sayesinde elde edilen kâğıt, metal ve plastiklerin kullanıldığı mobilyalar üzerinde çalışan sanatçılar arasında özellikle Ron Arad, Tom Dixon, Fred Baier, Fernando ve Humberto Campana eski araba koltukları, kullanılmayan rögar kapakları, paslı çelikler, atık kompakt diskler gibi malzemeler kullanarak tek örnek mobilyalar üretmiş ve yeni Brütalizm ekolünü oluşturmuşlardı. $\mathrm{Bu}$ tarz mobilyalar ergonomi ve kullanışlılık olarak çok başarılı sayılmıyordu. Değerli malzemelerin kullanılarak yapıldığı geleneksel el sanatı tasarımlarından çok uzak olan bu mobilyalar özenli el becerisi, heykelsi değerleri ve genelde tek örnek yapılmaları açısından tasarım değeri kazanmışlardır (Boyla, 2012, s.133). Yeşil tasarım sadece tasarımcıların değil; mobilya firmalarının da ilgi gösterdiği bir üslup olmuştur. $\mathrm{Bu}$ firmalar geri dönüşümlü malzemenin kullanıldığı mobilyalar üretmiş ya da eski mobilyaların yenilenmesi ve satışa sunulması hizmeti vermiştir. Yeşil tasarım kapsamında atık ürün kullanımı ve geri dönüştürülmüş malzeme kullanımı olmak üzere iki farklı tasarım şekli ortaya çıkmıştır. Yeşil tasarım kapsamında mobilya tasarımı zaman içinde mobilyada sürdürülebilirlik konusunu gündeme getirmiştir. Bu amaçla mobilyalarda işlevsellik, çok işlevlilik, modülerlik, yeniden kullanım, geri dönüşüm gibi hususlar tasarımın önemli ölçütlerini oluşturmuştur (Demirarslan ve Demirarslan, 2018, s.1057) (Şekil-12). Gün geçtikçe insanların çevrenin korunmasına karşı duyarlılık, eski eşyalarını ve mobilyalarını yeniden değerlendirme gibi konularda farkındalıklarının artması yeşil tasarım mobilya konusundaki çalışmalara destek olmaktadır. 

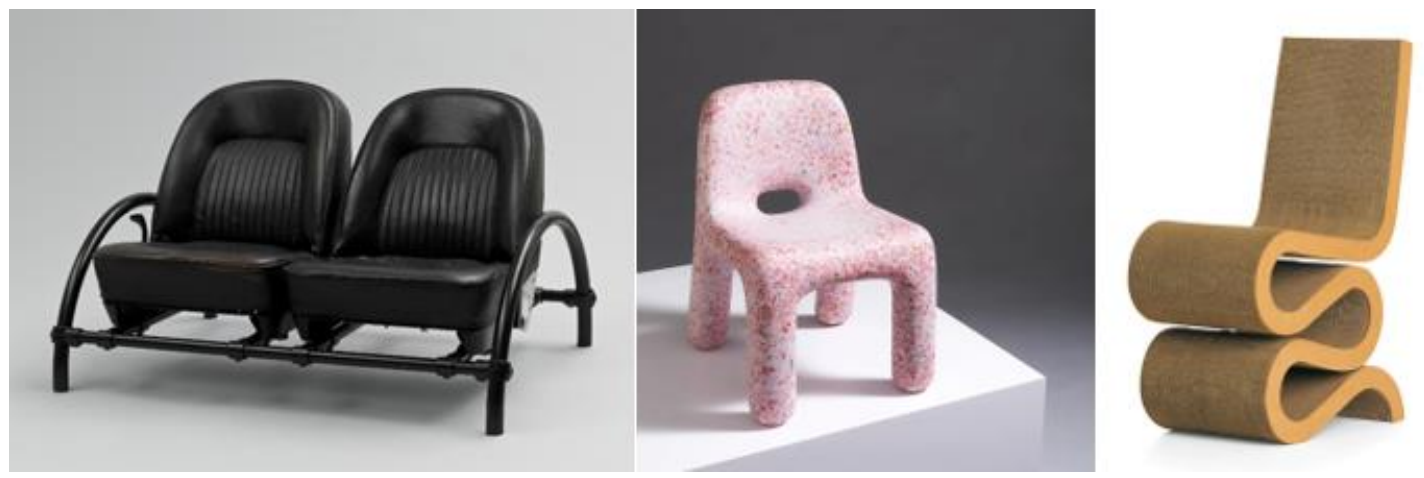

Şekil 12. Rover Chair, Ron Arad, 1981 (URL-20), Seramik Attklarından Yapılmış Sandalye Chair Charlie, Ecobirdy (URL21), Atık Kartondan Yapllmış Wiggle Side İskemle, Frank Gehry, 1972, (URL-22).

\subsubsection{Postmodernizm ve Memphis}

Bu terim ilk olarak 1960'lı yıllarda mimarlığın "Biçim işlevi izler" anlayışını izleyen Modernizm'den uzaklaşan biçimci, duygusal ve mantıksız bir kişilik kazanmaya başladığını düşünen eleştirmen Nicolaus Pevsner tarafından kullanılmıştır. İlk başlarda Postmodernizm yalnızca mimarlık alanı için kullanılırken, mimarlık alanındaki değişimlerin diğer tasarım alanlarında da yaşanmasıyla bu terim genel bir şekilde kullanılmaya başlanmıştır. Bu dönemin mimarları Modernizmde olduğu gibi bütüncül tasarım yaklaşımıyla aynı zamanda mobilya da tasarlamışlardır.

Hem bina, iç mekân hem da mobilya tasarlayan tasarımcılar arasında yer alan Amerikalı mimarlar yaptıkları tasarımlarda daha çok geçmiş akımları kullanıyorlardı. Michael Graves'in tasarımları 1930'lu yılların tasarım anlayışıyla çok benzerdi (Şekil- 13). Postmodernizm akımıyla tasarım yapan tasarımcılar genellikle bireysel tasarımlar ortaya koyarken, Memphis gibi grup halinde çalışan mobilya tasarım grupları da bulunmaktaydı. Ettore Sottsass tarafindan Milano'da kurulan bu tasarım grubu Nathalie du Pasquier, Michele de Lucchi, George Sowden, Aiata Isozaki, Michael Graves ile birlikte 1981 -1988 y1lları arasında aktif olarak tasarım yapmıştır. Memphis grubunun çalışmaları genellikle plastik, laminat ve seramik malzemeleri içeriyordu. Renkli ve soyut dekorasyonun yanı sıra asimetrik şekiller içeren bir tasarımla karakterize edilmiş, bazen keyfi olarak egzotik veya daha eski stillere ve tasarımlara atıfta bulunuyordu (Fitoussi, 1998, s.48). Bu örneklerden de görülmektedir ki Postmodernizm hem bir stil hem de bir yorumlamadır.

"İşlev biçimi izler" anlayışını temel alan Postmodernist mobilyaların en belirgin özelliği işlevi ikinci planda tutması ve biçime önem verilmesi, daha önce denenmemiş biçimlerin denenmesiydi. Güncel teknolojiyi ve en son malzemeleri kullanan tasarımcıların yanı sıra el işçiliğini tercih eden ya da bunları karıştırarak çalışan tasarımcılar da vardı. 1980'lerin ikinci yarısında oldukça karmaşık biçimlendirmeler uygulanıyordu. Bu dönemin tasarım anlayışında geçmiş ve şimdiki zaman, değerli ve adi, eski ve yeni, kaba ve ince iç içe yer almaktaydı. Minimalist anlayıştan uzak olan bu mobilyalardaki bir diğer özellik ise anıtsal ve heykelsel görünmeleriydi (Boyla, 2012, s.133-134). Michael Graves, Hans Hollein, Tomas Taveira, Peter Shire gibi tasarımcıların yön verdiği akımda zıtlıkların oluşturduğu bir uyum ile özgün tasarımlar ortaya konmuştur. 

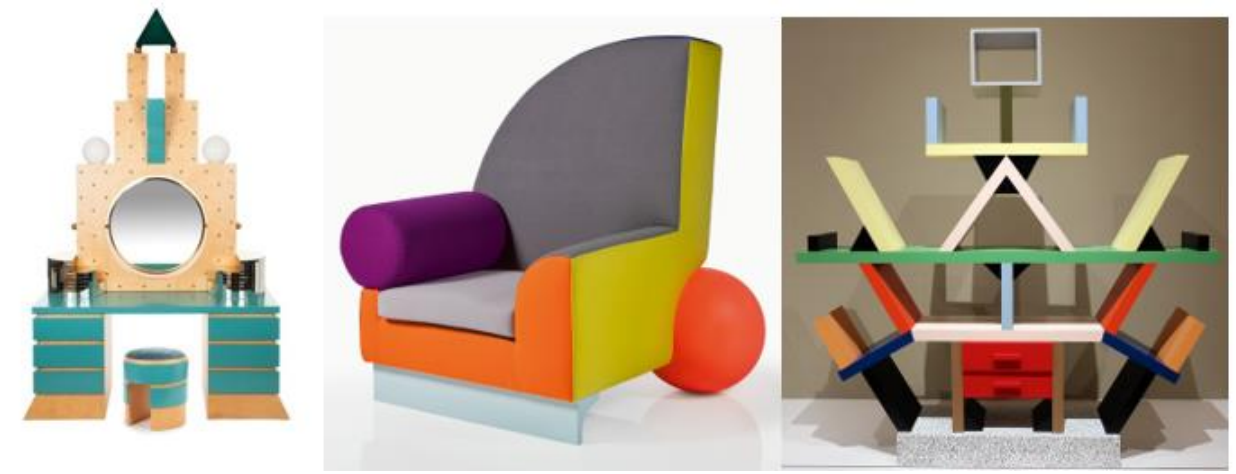

Şekil 13. Plaza, Michael Graves, 1981 (URL-23); Bel Air Chair, Peter Shire, 1982 (URL-24), Kitaplık, Ettore Sottsass, 1981 (URL-25).

\subsubsection{Minimalizm}

Postmodernizm'den sonra 80'li yılların sonlarından başlayan muazzam sadelikte tasarım anlayışı tüm dünyayı sarmıştır. Minimalizm 1960'larda Amerika'da plastik sanatçılarının arasında soyut resim ve heykel anlayışlarına karşıt olan bir tutuma verilmiş bir isimdir. Ancak 1900'lü yıllarda ressam Malevich'in renk, biçim ve form arayışı çalışmalarına dayanmaktadır (Islakoğlu, 2005, s.15). Donald Judd, Richard Serra ve Carl Andre gibi tasarımcılar yapıtlarında en gerekli ve en temel unsurları kullanıyor ve bu şekilde kendilerini ifade ediyorlardı. Mies van der Rohe'nin "Az çoktur" sözünün üzerine mimar Buckminster Fuller "Azla daha çok yapmak" ve tasarımcı Dieter Rams "Daha az ama daha iyi” sözleriyle aynı fikri paylaştıklarını belirtmişlerdir. Postmodernist tasarımların varlıklı kişilere göre az sayıda üretilmiş olması, kullanışsız olması ve oldukça güçlü görsel etkileri sebebiyle akımdan çabuk vazgeçilmesine neden olmuştur. 90'lı yıllara gelindiğinde her türlü tasarımı görmüş, gereksinimler karşılanmış ve oldukça doymuş durumda bir tüketici grubu bulunmaktaydı. Kullanıcılar gösterişli ama işlevsiz, kullanışsız mobilyalardan bıkmıştı. Bu sebeple sade, kullanışlı ve ucuz tasarımlara ihtiyaç vardı. Dönemde yaşanan teknolojik gelişmeler sayesinde projelendirme ve üretim kolay hale geliyordu. Yeni yapay malzemeler ile mobilyaların ince bacakları yük taşıyabiliyor, akıllı plastiklerle tek parça ile mobilyada olması gereken ergonomi, esneklik, geçirgenlik, saydamlık gibi gereksinimlere cevap alınabiliyordu (Boyla, 2012, s.139-140). Aslında minimalist mobilya anlayışı Bauhaus ile görülmeye başlanmış, Modernizm ile devam etmiştir. Marcel Brauer, Mies Van Der Rohe, Le Corbusier gibi tasarımcıların tasarımları minimalist tasarımlardı. Tek renkli, şeffaf ve bütünleşik görünümlü Minimalizmin mobilya tasarımındaki ilkeleri ciddi direktifler içerir: Formları azaltın, renk paletlerini sınırlandırın, israfı ortadan kaldırın (Meyer ve Meyer, 2004) (Şekil-14). Kısacası Minimalizm; bir tasarımı minimum sayıda renk, değer, biçim, çizgi, doku ve malzemeye indirgeyerek ifade etme olarak tanımlanabilir.

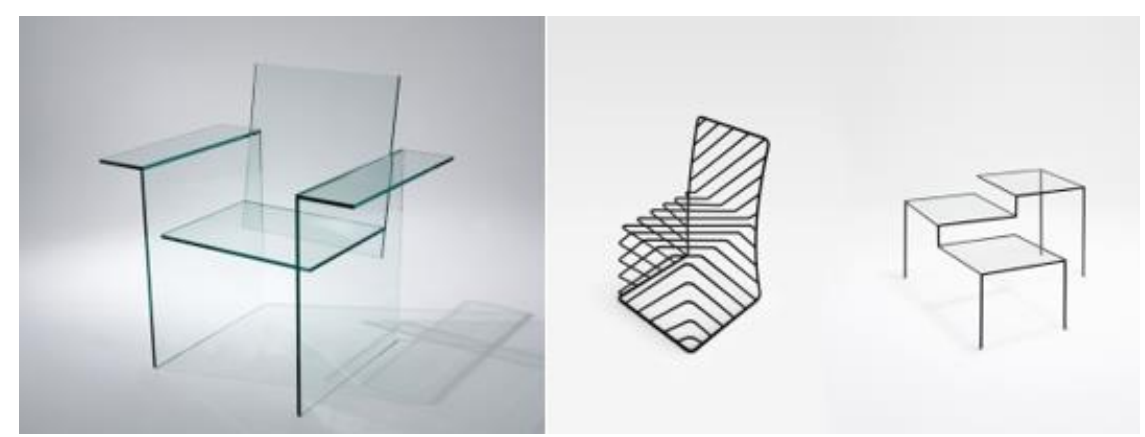




\subsubsection{Organik Tasarım}

1950'lerden sonra endüstri üretimi sonucunda ortaya çıkan ürünlerin estetik açıdan değerleri tartışılırken canlı organizmaları incelemek, yapılarındaki uyumları anlamak ve bunları kopyalamak, sanatçılar tarafından benimsenmişti. Bu düşünce el sanatçıları tarafından uygulanmış ve bu akımda etkileri büyük olmuştur. Organik terimi ilk olarak iki savaş arasındaki dönemde Amerika'da ortaya çıkmıştır. "Organik Modern" olarak da tanımlanmaktadır. Önce mimarlık alanında organik tasarımlar görülmüştür. Frank Llyod Wright, Alvar Aalto Organik mimarlığın temsilcileri olarak kabul edilirken; mobilyada organik tasarım ise ilk olarak 1939 senesinde MoMA'nın yarışması ile gündeme gelmiştir (URL-28). Yarışmada seçilen mobilyaların özelliği insan bedenini sarabilen biçimde olmalarıydı. Amerikalı endüstri tasarımcısı olan Henry Dreyfuss'ın yaptığı insan boyutları ve ergonomi çalışmaları tasarımda insan konusunu gündeme getirmişti. 1980'li yıllardan sonra yapılan çalışmalar ile doğal malzemelerin özelliklerini barındıran bazı yapay malzemelerin elde edilmesiyle 1990'larda organik ürünler artık bu malzemeler ile üretiliyordu. Organik kelimesi, mobilyanın veya eşyanın insanlara sadece biçimsel olarak uyum sağlamasının yanı sıra, koşullara göre değişim gösterebilme, farklı canlılara özgü birtakım hareketleri yapabilme, 1s1, 1ş1k ve ses kontrol edebilmeyi de barındırıyordu (Boyla, 2012, s.141). Organik tasarım mobilya denilince akla ilk gelen tasarımcı Eero Saarinen'dir. Saarinen "Ev Mobilyalarında Organik Tasarımlar" adlı yarışmada birinci gelmesini sağlayan Lale Sandalye ile Organik Tasarım konusunda önemli bir çalışma ortaya koymuştur. Zamanla teknoloji geliştikçe Ross Lovegrove, Marc Newson, Warren Platner, Joe Colombo, Harry Bertoia, George Nelson gibi tasarımcıların çalışmalarıyla farklı gereçlerle organik tasarım mobilyaların yapımı devam etmiştir (Şekil-15).
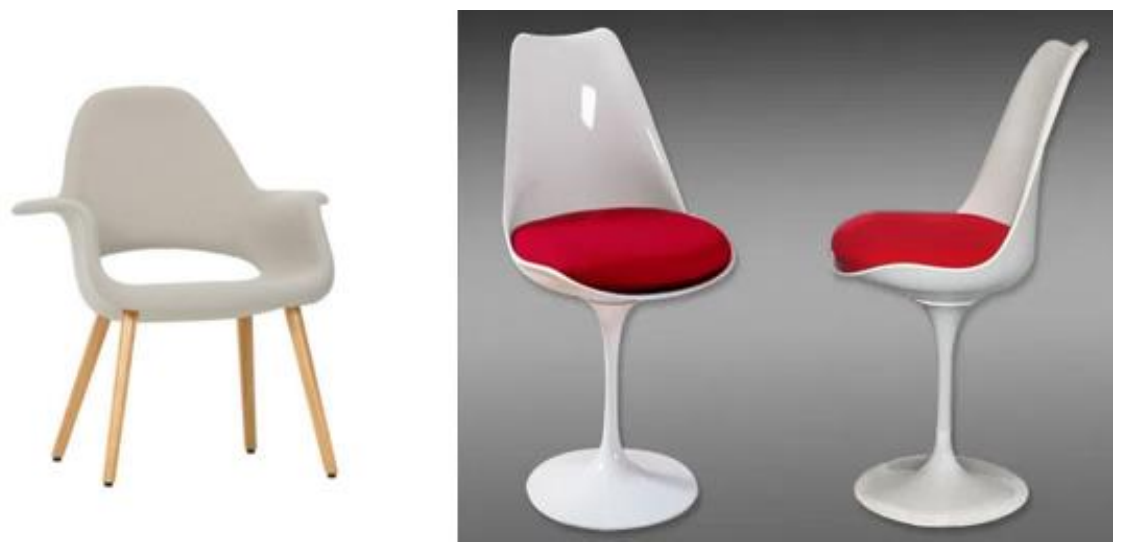

Şekil 15. Organic Chair, Charles Eames \& Eero Saarinen, 1940 (URL-29); Lale Sandalye Eero Saarinen,1940 (URL-30).

İçinde bulunduğumuz 21. Yüzyıl, Modernizmin etkilerinin devam ettiği Vintage ve Yeni Barok ya da diğer adıyla Modern Barok, Hi-tech gibi eski tasarımlara atıfta bulunan yeni üslup arayışlarının yer aldığı bir dönemdir. Çağdaş "Yeni Modernist" tasarımlar, Modernizm ilkelerine sayg1 göstermekte; basit ergonomik formlar ve bilinçli olarak doğaldan yenilikçi sentetiklere kadar değişen malzemelerle işleve odaklanan tasarımlar ortaya koymaktadır. Organik ve modern formlara geri dönmenin yanı sıra, Zaha Hadid, Frank Gehry gibi çağdaş mimar-tasarımcılar tarafından akışkan kalıplanmış organik formları yeniden keşfetmek için modern malzemeler kullanan bir tasarım anlayışı ön plana çıkmaktadır. Çevresel etki ile ilgili endişeler, giderek daha teknolojik hale gelen mekân ortamları için çevreci mobilyaların üretimini desteklemektedir. Ayrıca Barok üslubun çağdaş yorumları Philippe Starck gibi tasarımcılar tarafından mobilya tasarımına yön vermektedir. Tüm bu mobilyalar oldukça faydac1, minimal ve heykelsidir (Şekil-16). 

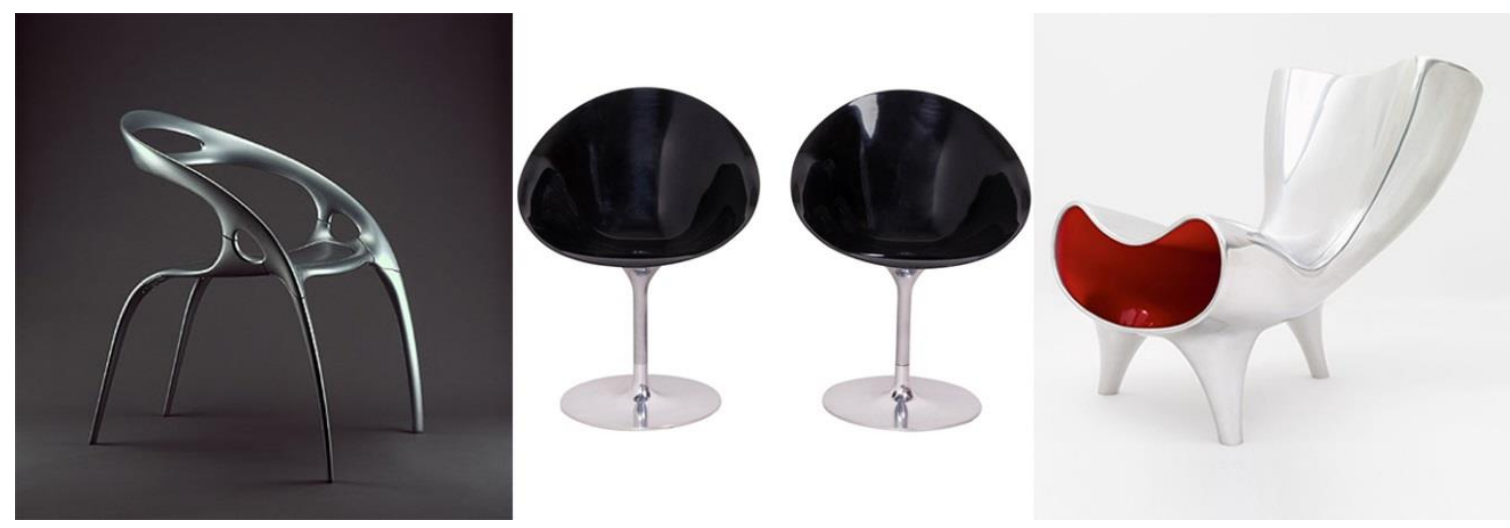

Şekil 16. Go Chair, Ross Lovegrove, 1998-2001, (URL-31); Ero/S Black Chairs, Philippe Starck 1999, (URL-32); Orgone Chair, Marc Newson, 1993, (URL-33).

\section{Bulgular}

Şimdiye kadar verilen bilgiler ışı̆̆ında 20. Yüzyıldaki mobilya akımları, bu akımların genel özellikleri ve önde gelen tasarımcıları ile örnek tasarımlar bir tablo halinde özetlenmektedir. İkinci Dünya Savaşı öncesi ve sonrası görülen tüm akımlarda genellikle bütüncül tasarım anlayışı ile tasarımcıların tasarımlar üretmeleri söz konusudur. İkinci Dünya Savaşı öncesi başlayan Modernizm İkinci Dünya Savaşı sonrası görülen tüm akımların ortaya çıkışını etkilemiştir. Tüm akımlar Modernizmin "biçim işlevi izler" manifestosuna paralel ya da zit olacak şekilde gelişim göstermiştir. Yirminci yüzyıl boyunca mobilya tasarımının, mimarların, iç mimarların ve endüstriyel ürün tasarımcılarının kesiştiği ortak bir konu olduğu görülmüştür. İkinci Dünya Savaşı öncesinde işlev ve stil 1950'lerde işlev ve stil, 1960 ve 70'li y1llarda teknoloji, gereksinim ve estetik, 80'li y1llarda anlam, 90'l1 y1llarda ise deneysellik ve faydacılık mobilya tasarımında en etkili olan unsurlar olarak karşımıza çıkmaktadır.

Tablo-2: 20.Yüzyılda Mobilya Akımlarının Genel Özellikleri

\begin{tabular}{|c|c|c|c|}
\hline DÖNEM & $\begin{array}{c}\text { GENEL } \\
\text { ÖZELLÍKLER }\end{array}$ & $\begin{array}{l}\text { ÖNDE GELEN } \\
\text { TASARIMCILAR }\end{array}$ & $\begin{array}{l}\text { ÖRNEK } \\
\text { TASARIM }\end{array}$ \\
\hline \multicolumn{4}{|l|}{$\begin{array}{c}\text { İKİNCİ DÜNYA SAVAŞI ÖNCESİ } \\
\text { DÖNEM }\end{array}$} \\
\hline $\begin{array}{l}\text { MODERNİZME GİRIŞ (1910- ) ve } \\
\text { KUBİZM }\end{array}$ & $\begin{array}{l}\text { Sadelik, işlevsellik, } \\
\text { bütüncül tasarım } \\
\text { anlayışı, temel } \\
\text { geometrik formlar }\end{array}$ & $\begin{array}{c}\text { Joseph Gocar } \\
\text { Adolf Loos } \\
\text { Le Corbusier } \\
\text { Charlotte Perriand }\end{array}$ & $\begin{array}{c}\text { Joseph Gocar } \\
\text { tasarımı } \\
\text { mobilyalar }\end{array}$ \\
\hline DE STIJL (1917- ) & $\begin{array}{l}\text { Asimetri, dik açılı } \\
\text { formlar, ana renkler, } \\
\text { Yalınlık, sanatsal sezgi, } \\
\text { evrensellik, teknik, } \\
\text { pratiklik ve estetik } \\
\text { uyumun iç içe olması }\end{array}$ & $\begin{array}{l}\text { Gerrit Rietveld, } \\
\text { Theo Van Doesburg }\end{array}$ & $\begin{array}{l}\text { Red and Blue } \\
\text { iskemle } \\
\text { Zigzag } \\
\text { iskemle }\end{array}$ \\
\hline
\end{tabular}




\begin{tabular}{|c|c|c|c|}
\hline BAUHAUS (1919- ) & $\begin{array}{l}\text { Endüstriyel malzeme } \\
\text { kullanımı, hafiflik, } \\
\text { hijyen, biçimde yalınlık, } \\
\text { konstrüktif yapı, } \\
\text { strüktürün açıça } \\
\text { görülmesi, detaylarda } \\
\text { basitlik, ana renklerin } \\
\text { kullanımı, rengin işlevi } \\
\text { ve strüktürü } \\
\text { tanımlaması, bütüncül } \\
\text { tasarım anlayışı, metal, } \\
\text { cam ve deri malzemenin } \\
\text { kullanımı }\end{array}$ & $\begin{array}{c}\text { Marcel Breuer } \\
\text { Mies van der Rohe } \\
\text { Erich Dieckmann } \\
\text { Peter Keller } \\
\text { Alma Buscher }\end{array}$ & $\begin{array}{l}\text { Barcelona } \\
\text { iskemle, } \\
\text { Wassily } \\
\text { iskemle }\end{array}$ \\
\hline ART DECO (1925- ) & $\begin{array}{l}\text { Geometrik desenler, } \\
\text { sedef, abanoz, fildişi, } \\
\text { gümüş, altın, leopar ve } \\
\text { kaplan postlarıyla parlak } \\
\text { renklere sahip ipek } \\
\text { kumaşlar, marketöri, } \\
\text { lüks ve pahalı } \\
\text { tasarımlar, Streamline } \\
\text { çizgisi }\end{array}$ & $\begin{array}{c}\text { Léon Jallot } \\
\text { Jacques-Emile } \\
\text { Ruhlmann } \\
\text { Eileen Gray } \\
\text { Andre Leleu }\end{array}$ & Day Bed \\
\hline \multicolumn{4}{|c|}{$\begin{array}{l}\text { İKİNCİ DÜNYA SAVAŞI SONRASI } \\
\text { DÖNEM }\end{array}$} \\
\hline MODERNİM & $\begin{array}{l}\text { Seri üretim, düz çizgi, } \\
\text { daire, kare, prizma ve } \\
\text { silindir gibi doğada } \\
\text { bulunmayan basit } \\
\text { geometrik biçimler, } \\
\text { strüktürün açıça } \\
\text { görülmesi, kırmızı, sarı, } \\
\text { mavi yanında siyah, } \\
\text { beyaz ve gri renk } \\
\text { kullanımı, oran, orantı, } \\
\text { ergonomi, bütüncül } \\
\text { tasarım anlayışı }\end{array}$ & $\begin{array}{c}\text { Isamu Noguchi } \\
\text { Marcel Breuer } \\
\text { Eileen Gray } \\
\text { Jos De Mey } \\
\text { Pierre Jeanneret } \\
\text { Charlotte Perriand } \\
\text { Mies Van Der Rohe } \\
\text { Le Corbusier }\end{array}$ & $\begin{array}{c}\text { Noguchi } \\
\text { Table, } \\
\text { Lounge Chair }\end{array}$ \\
\hline İSKANDİNAV MODERNIZMI & $\begin{array}{l}\text { Minimalizm ve } \\
\text { işlevsellik, doğal ahşap } \\
\text { ve kontrplak kullanımı, } \\
\text { algılanabilir strüktür }\end{array}$ & $\begin{array}{c}\text { Alvar Aalto } \\
\text { Arne Jacobsen } \\
\text { Borge Mogensen } \\
\text { Hans J. Wegner } \\
\text { Verner Panton }\end{array}$ & $\begin{array}{l}\text { Paimio } \\
\text { Sandalye }\end{array}$ \\
\hline POP-ART (1950- ) & $\begin{array}{l}\text { Plastik malzeme } \\
\text { kullanımı, çok renkli ve } \\
\text { eğlenceli tasarımlar, } \\
\text { popülarite }\end{array}$ & $\begin{array}{c}\text { Allen Jones } \\
\text { Paolo Lomazzi } \\
\text { George Nelson } \\
\text { John Makepeace } \\
\text { Fred Baier } \\
\text { Alan Paters } \\
\end{array}$ & $\begin{array}{l}\text { Marshmallow } \\
\text { Sofa }\end{array}$ \\
\hline ULUSLARARASI STİL (1960- ) & $\begin{array}{l}\text { Sentetik malzeme } \\
\text { kullanımı, sınırsız renk } \\
\text { çeşitliliği, sadelik, çok } \\
\text { hareket bulunmayan } \\
\text { akıcı hatlar, detay } \\
\text { yetkinliği }\end{array}$ & $\begin{array}{l}\text { Arne Jacobsen } \\
\text { Warren Platner } \\
\text { Charles Eames } \\
\text { Ray Eames }\end{array}$ & Egg Chair \\
\hline HI-TECH (1960- ) & $\begin{array}{l}\text { Metal, cam, plastik gibi } \\
\text { işlenmiş olan } \\
\text { malzemelerin kullanımı, } \\
\text { minimalist tasarım, tek } \\
\text { renk kullanımı, } \\
\text { modülerlik }\end{array}$ & $\begin{array}{l}\text { Rodney Kinsman } \\
\text { Michael Hopkins } \\
\text { Richard Rogers }\end{array}$ & $\begin{array}{l}\text { Omkstak } \\
\text { Chair }\end{array}$ \\
\hline
\end{tabular}




\begin{tabular}{|c|c|c|c|}
\hline YEŞİL TASARIM (1970- ) & $\begin{array}{l}\text { Çevreci yaklaşım, geri } \\
\text { dönüşüm malzeme } \\
\text { kullanımı, işlevsellik, } \\
\text { çok işlevlik, modülerlik, } \\
\text { yeniden kullanım, geri } \\
\text { dönüşüm }\end{array}$ & $\begin{array}{c}\text { Ron Arad } \\
\text { Tom Dixon } \\
\text { Fred Baier } \\
\text { Fernando ve Humberto } \\
\text { Campana }\end{array}$ & $\begin{array}{l}\text { Rover Chair, } \\
\text { Favela Chair }\end{array}$ \\
\hline $\begin{array}{l}\text { POSTMODERNIZM ve MEMPHIS } \\
(1980-)\end{array}$ & $\begin{array}{l}\text { Biçim, plastik, laminat } \\
\text { ve seramik malzeme } \\
\text { kullanımı, çok renkli, } \\
\text { asimetrik, eski stillere } \\
\text { atıfta bulunma, anıtsal } \\
\text { ve heykelsi, grup } \\
\text { tasarımı }\end{array}$ & $\begin{array}{c}\text { Ettore Sottsass } \\
\text { Michael Graves } \\
\text { Nathalie du Pasquier } \\
\text { Michele de Lucchi } \\
\text { George Sowden } \\
\text { Aiata Isozaki } \\
\text { Hans Hollein } \\
\text { Tomas Taveira }\end{array}$ & $\begin{array}{l}\text { Bel Air } \\
\text { Chair, Ettore } \\
\text { Sottsass } \\
\text { tasarımı } \\
\text { kitaplık }\end{array}$ \\
\hline MİNIMALIZM (1980 SONLARI) & $\begin{array}{l}\text { Minimalist tasarım, tek } \\
\text { renkli, şeffaf, } \\
\text { bütünleşik, yalın form }\end{array}$ & $\begin{array}{l}\text { Shiro Kuramata } \\
\text { Donald Judd } \\
\text { Richard Serra } \\
\text { Carl Andre }\end{array}$ & Glass Chair \\
\hline ORGANIK TASARIM (1990- ) & $\begin{array}{l}\text { İnsan bedenine uyumlu } \\
\text { biçimler }\end{array}$ & $\begin{array}{c}\text { Ross Lovegrove } \\
\text { Marc Newson } \\
\text { Warren Platner } \\
\text { Joe Colombo } \\
\text { Harry Bertoia } \\
\text { George Nelson }\end{array}$ & $\begin{array}{c}\text { Lale } \\
\text { Sandalye, } \\
\text { Organik } \\
\text { iskemle }\end{array}$ \\
\hline
\end{tabular}

\section{Sonuç}

20.yüzyılda ekonomik, siyasi, politik, sosyo-kültürel alanlarda görülen değişimlerin ve küreselleşmenin etki ettiği ana noktalardan birisi de mobilya alanıdır. Dünya savaşları neticesinde toplum yapısının ve günlük yaşam kalıplarının değiştiği bu dönem endüstrileşmenin de gelişmesi ile birlikte mobilya alanında teknolojik ve tasarımsal yeniliklere yol açmıştır. Bu gelişim ve yenilikler birçok üslubun ortaya çıkmasını sağlamıştır. $\mathrm{Bu}$ mobilya tasarım üsluplarının birçoğunun mimarlıkla yakından ilişkili olduğu görülmektedir (Tablo-1). Bu dönemdeki mobilya tasarım üsluplarının çoğunun temelinde ise modernizm yer almaktadır (Tablo-2). Modernizmin "az çoktur" ilkesi zamanla minimalist yaklaşımı getirmiş ve Postmodernizm ve Art Deco dışındaki üslupların temel felsefesini oluşturmuştur. Postmodernizm, Modernizme karşıt olarak çıktığından yine Modernizm ile ilgili bir üsluptur. Kısaca söylemek gerekirse Modernizm ve minimalist tasarım yaklaşımı 20.yüzyıla damgasını vurmuştur. "Az çoktur" ilkesi yüzyılın sonlarına doğru mobilya tasarımında çevreci yaklaşımı gündeme getirmiş; mobilya malzeme ve yapım teknolojinin gelişimi ile birlikte geçmiş dönem üsluplarına atıfta bulunan yeni tasarım anlayışları ortaya çıkmaya başlamıştır. 20. yüzyıl; çok sayıda üretilmiş özgün, yaratıcı ve orijinal mobilyaları, yeni malzeme çeşitleri ve teknolojileri ile 21. yüzyıldaki yeni gelişmelere 1şık tutmaktadır.

20.yüzyılın ilk yarısında, mobilya üretiminde işlevsellik, erişilebilirlik, ergonomi tasarımda önemli ölçütler olarak yerleşmiştir. "Biçim işlevi izler" ve "İşlev biçimi izler" olarak iki önemli manifesto içeren bu yüzyılda Postmodern tasarımlar dışında işlev biçimin oluşmasında etkin bir unsur olarak görülmektedir. Mobilya tasarımcılarının birden fazla üslupta isimlerini ve tasarımlarını görmek mümkündür. Bu durum üslupların çoğunun temelinde Modernizm ve minimalist yaklaşımın yer almasından kaynaklanmaktadır. Yalın, süsten arınmış, insan ve mekân ile uyumlu, malzemenin kendi rengi ve dokusunun tasarımda hissedildiği bu mobilyalar gelecek yüzyılın mobilya üslupları için de temel teşkil etmekte ve akıllı teknolojiler ile birlikte kullanımlarıyla mobilya tasarımında gelecekçi yaklaşımlara olanak sağlayacağı düşünülmektedir. Kısaca söylemek gerekirse tarihin eski dönemlerinden 
itibaren sürekli gelişim gösteren mobilya tasarımı alanında 20.yüzyılda yaşanan gelişimler 21 . Yüzyıl ve ötesinde kullanılacak olan mobilyalar için bir dönüm noktası olmuştur.

\section{Kaynakça}

Ambrose, G. ve Harris, P. (2010). Görsel Grafik Tasarım Sözlüğü, Çeviren Bilge Barhana, İstanbul: Literatür Yayıncılık.

Ateş, Y. (2014). Konut İç Mekân Mobilyasının Gelişim Sürecini Etkileyen Faktörlerin Irdelenmesi, Haliç Üniversitesi, Fen Bilimleri Enstitüsü, İstanbul. Y. Lisans Tezi.

Boyla, O. (2012) Mobilya Tarihi.

Bulat, S. Bulat, M. Aydın, B. (2014). Bauhaus Tasarım Okulu, Atatürk Üniversitesi Sosyal Bilimler Enstitüsü Dergisi 201418 (1): 105-120.

Demirarslan, D, Demirarslan, O. (2020). Digital Technology and Interior Architecture. Mimarlık ve Yaşam Dergisi, 5 (2), 561-575. DOI: 10.26835/my.787081

Demirarslan, K.O., Demirarslan, D. (2018). Methods and Recommendations on Evaluation of Furniture Wastes from Ecological Aspects, The Most Recent Studies in Science and Art, Ed. Hasan Arapgirlioğlu, Atilla Atik, Salim Hızıroğlu, Robert Elliot, Dilek Atik, Gece Kitaplı̆̆ 1 , 1057-1068.

Droste, M. (2002). The Bauhaus, 1919-1933: Reform and Avant-Garde. Köln: Taschen.

Eriç, M., Ersoy, H., Yener, E. (1986). Günümüz Konutunda Rasyonel Donatım, Teknografik Matbaas1, İstanbul.

Fiell, C. (2003). Scandinavian Design, 2003, Köln: Taschen.

Fiell, C., Fiell, P. (2012). Design of the 20th Century. Köln: Taschen

Fitoussi, B. (1998). Memphis, Thames \& Hudson.

Gössel, P. (1990). Functional Architecture: International Style ,1925-1940. Taschen.

Islakoğlu, P, M. (2005). Mimarlıkta Minimalizm, Ege Mimarlık Dergisi, 3-55, 14-19

Işıkkaya, A.D. (2015). Loft Tipi Konutların Başkalaşım Süreci Bağlamında Türkiye'de Loft Kavramının Analizi: Levent Loft Örneği. Megaron, Istanbul Vol. 10, Iss. 2, 205-223. DOI: 10.5505/megaron.2015.42714

Julier, G. (1993). Encylopedia of 20th Century Design and Designers. Londra: The Thames and Hudson.

Khan, H. (1998). International Style: Modernist Architecture from 1925 to 1965. Almanya: Taschen.

Kron, J., Slesin, S., (1984). High-Tech: The Industrial Style and Source Book For the Home.

Massey, A. (1996). Interior Design of the 20th Century. London: Thames\& Hudson Ltd.

Meyer, J., Meyer, S., J. (2004). Minimalism: Art and Polemics in the Sixties.Yale University Press.

Mori, T., Ohbuchi Y., Iida, H., Tsukamoto, K., Nakamura, Y. \& Sakamoto, N. (2016). "Study of optimum shape and strength design of the redesigned Zig-Zag chair", Proceedings of the 2 International Conference on ndHigh Performance and Optimum Design of Structures and Materials. WIT Transactions on The Built Environment, Vol 166, 255-265. New York: Published by Clarkson. 
Özakın, D. (2018). Art Nouveau Akımının Rus Sanat Dünyasında Yorumlanması: Rus Stili. Art-Sanat Dergisi, (9), 241-251.

Say, Ö. (2003). 20. Yüzyılda Yaşanan Sosyal Değişme Dinamikleri ve Kültürel Çözümlemeler Açısından Küreselleşme. Sosyoloji Konferansları Dergisi. Sayı 28, 6176.

Sembach, K.J. Neret, G. Leuthauser, G., Gosse, P. (1994). 20th Century Furniture Design. Edinburgh: Elvis Shakespeare Ltd .

Sofuoğlu, Ü., Ertaş, Ş., Sönmez, E. (2019). De Stijl Dönemi Gerrit Rietveld Mobilya Tasarımlarında Renk Kavramı. International Social Sciences Studies Journal, Vol:5, Issue:50, 6751-6760.

Şahinkaya, S.B. (2009). Bauhaus Mobilya Tasarımının Günümüz Mobilya Tasarımına Etkileri. İTÜ, Sosyal Bilimler Enstitüsü, İstanbul. Y. Lisans Tezi.

Şekercioğlu, S. (2017). Mobilyanın Gelişim Süreci ve Doğu-Batı Sentezinin Osmanlı Mobilyası Üzerindeki Etkisinin İncelenmesi, Haliç Üniversitesi, Fen Bilimleri Enstitüsü, İstanbul. Y. Lisans Tezi.

\section{Internet Kaynakları}

URL-1: https://www.britannica.com/art/Arts-and-Crafts-movement (Erişim Tarihi: 14.10.2020)

URL-2: https://www.ngv.vic.gov.au/essay/there-is-no-modern-furniture-adolf-loos-and-theviennese-apartment-of-jakob-and-melanie-langer-2/ (Erişim Tarihi: 14.10.2020)

URL-3: https://openhousebcn.wordpress.com/2013/04/15/openhouse-magazine-match-madein-france-architecture-furniture-design-le-corbusier-charlotte-perriand/ (Erişim Tarihi: 14.10.2020)

URL-4: https://cherylhoward.com/house-of-the-black-madonna-prague/ (Erişim Tarihi: 22.10.2020)

URL-5: https://fineartamerica.com/featured/the-red-and-blue-chair-ivory-kenneth-perez.html4 (Erişim Tarihi: 22.10.2020)

URL-6: https://pin.it/4nO6hUX (Erişim Tarihi: 08.11.2020)

URL-7: https://www.elledecor.com/it/best-of/a27271476/marcel-breuer-works/ (Erişim Tarihi: 08.11.2020)

URL-8: https://www.knoll.com/product/barcelona-chair (Erişim Tarihi: 08.11.2020)

URL-9: https://www.art.com/products/p13050725-sa-i2298233/nelson-and-edith-dawsonducharmebronz-a-rosewood-and-gilt-bronze-day-bed-designed-by-jacques-emileruhlmann-1879-1933.htm (Erişim Tarihi: 13.11.2020)

URL-10: https://imgur.com/r/ArtDeco/6inDCJl (Erişim Tarihi: 13.11.2020)

URL-11: https://www.incollect.com/listings/furniture/seating/jos-de-mey-pair-of-modernisteasy-chairs-176028 (Erişim Tarihi: 13.11.2020)

URL-12: https://study.com/academy/lesson/modernist-furniture-history-designers.html\#: :te $\mathrm{xt}=$ Modernism\%20used\%20new\%20materials\%20and,and\%20ended\%20around $\% 20 \mathrm{t}$ he\%201950s (Erişim Tarihi: 13.11.2020)

URL-13: https://www.scandinavia-design.fr/Home/about-scandinavian-design.html (Erişim Tarihi: 16.11.2020) 
URL-14: https://www.smow.com/en/manufacturers/vitra/marshmallow-sofa.html (Erişim Tarihi: 16.11.2020)

URL-15: https://www.researchgate.net/publication/274513100_Breaking_the_language_of_ design Semioclastics_in_the_world_of_industrial_design/figures?lo=1 (Erişim Tarihi: 16.11.2020)

URL-16: https://www.pinterest.com.mx/pin/592856738437997044/ (Erişim Tarihi: 18.11.2020)

URL-17: https://www.artsy.net/artwork/charles-and-ray-eames-dax-shell-armchair (Erişim Tarihi: 18.11.2020)

URL-18: https://www.vinterior.co/furniture/seating/occasional-chairs/original-omkstak-steelstacking-chair-by-rodney-kinsman-for-omk (Erişim Tarihi: 18.11.2020)

URL-19: https://vevotpl.com/media/z59MraMKad96 (Erişim Tarihi: 18.11.2020)

URL-20: https://fi.pinterest.com/pin/622552348460801283/ (Erişim Tarihi: 23.11.2020)

URL-21: https://www.architecturaldigest.com/gallery/eco-friendly-furniture-designs (Erişim Tarihi: 23.11.2020)

URL-22: https://www.dezeen.com/2014/12/23/a-zdvent-calendar-wiggle-chair-frank-gehry/ (Erişim Tarihi: 23.11.2020)

URL-23: https://www.semaine.com/shop/michael-graves-for-memphis-milano-plaza (Erişim Tarihi: 23.11.2020)

URL-24: https://www.dezeen.com/2016/10/17/five-best-most-iconic-david-bowie-memphisfurniture-design-collection-sothebys-auction-london/ (Erişim Tarihi: 23.11.2020)

URL-25: https://en.wikipedia.org/wiki/Memphis_Group\#/media/File:Ettore_sottsass_per _memphis_srl,_libreria_carlton,_milano_1981.jpg (Erişim Tarihi: 23.11.2020)

URL-26: https://www.artsy.net/artwork/shiro-kuramata-glass-chair (Erişim Tarihi: 27.11.2020)

URL-27: https://www.pamono.com/stories/minimalist-furniture-design-history-essence (Erişim Tarihi: 27.11.2020)

URL-28: https://www.moma.org/documents/moma_catalogue_1803_300190105.pdf(Erişim Tarihi: 27.11.2020)

URL-29: https://cubegallery.co.za/product/organic-chair/ (Erişim Tarihi: 27.11.2020)

URL-30: https://www.tasarimakademi.org/eero-saarinen-organik-mobilya-tasarimcisi.html (Erişim Tarihi: 27.11.2020)

URL-31: https://katebarclay.blogspot.com/2009/09/video-reflection-ross-lovegroveorganic.html (Erişim Tarihi: 23.04.2021)

URL-32: https://www.pamono.eu/ero-s-black-chairs-by-philippe-starck-for-kartell-set-of-2 (Erişim Tarihi: 23.04.2021)

URL-33: https://marc-newson.com/orgone-chair/ (Erişim Tarihi: 23.04.2021) 